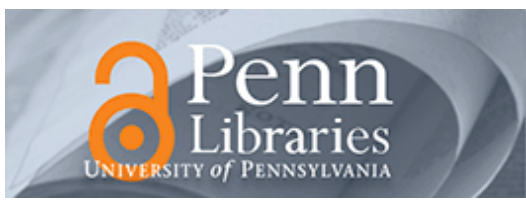

University of Pennsylvania ScholarlyCommons

Wharton Pension Research Council Working

Papers

Wharton Pension Research Council

$10-1-2013$

\title{
Contagious Runs in Money Market Funds and the Impact of a Government Guarantee
}

Hugh Hoikwang Kim

Sungkyunkwan (SKK) University, h.kim@skku.edu

Follow this and additional works at: https://repository.upenn.edu/prc_papers

Part of the Economics Commons

Kim, Hugh Hoikwang, "Contagious Runs in Money Market Funds and the Impact of a Government Guarantee" (2013). Wharton Pension Research Council Working Papers. 137.

https://repository.upenn.edu/prc_papers/137

This paper is posted at ScholarlyCommons. https://repository.upenn.edu/prc_papers/137

For more information, please contact repository@pobox.upenn.edu. 


\title{
Contagious Runs in Money Market Funds and the Impact of a Government Guarantee
}

\begin{abstract}
Despite a vast theoretical literature on contagious behavior of investors, little is known about its empirical evidence in a real financial crisis setting. This paper examines evidence for contagious runs in money market funds during the 2008 financial crisis, drawing on a rich data set tracking U.S. money market funds' daily flows and their enrollment statuses in the Treasury Department's Temporary Guarantee Program (TGP). Evaluating the positive externality effect from a peer fund's enrollment in the TGP on non-enrolled funds, we show that panic-driven runs were contagious across funds. We find that funds' stability due to their enrollment in the guarantee program spilled over and enhanced daily flows to a non-enrolled fund by $\$ 1.8$ million compared to already-enrolled funds. Moreover, we find that retail investors were less likely than institutional investors to return to prime money market funds even after enrollment in the guarantee program, implying that the latter benefited more from the government back-stop. Results are germane to policies seeking to rebuild investor confidence in times of financial crises and reduce the chance of future contagion in this industry.
\end{abstract}

\section{Disciplines}

Economics 


\title{
Contagious Runs in Money Market Funds and the Impact of a Government Guarantee
}

\author{
Hugh Hoikwang Kim
}

October 2013

\author{
PRC WP2013-31 \\ Pension Research Council Working Paper \\ Pension Research Council \\ The Wharton School, University of Pennsylvania \\ 3620 Locust Walk, 3000 SH-DH \\ Philadelphia, PA 19104-6302 \\ Tel: 215.898.7620 Fax: 215.573.3418 \\ Email: prc@wharton.upenn.edu \\ http://www.pensionresearchcouncil.org
}

I thank Franklin Allen, Santosh Anagol, Peter Blair, Peter Crane, Alex Edmans, Fernando Ferreira, Itay Goldstein, Todd Gormley, Daniel Gottlieb, Kumar Kesavan, Raimond Maurer, Olivia S. Mitchell, David Musto, Thien Nguyen, Greg Nini, Nick Roussanov, Paula Tkac, Jeremy Tobacman, Petra Todd, and seminar participants at George Mason University, Nanyang Business School, SKK Graduate School of Business, Temple University, University of Cincinnati, University of New South Wales, University of Illinois at Chicago, the Wharton School and the 2012 FMA Doctoral Student Consortium for helpful discussions and comments. I gratefully acknowledge research support from the Bradley Foundation, the Pension Research Council/Boettner Center, and the S.S. Huebner Foundation at the Wharton School of the University of Pennsylvania. All errors are my own. (C) 2013 Kim.

All opinions, errors, findings, interpretations, and conclusions of this paper represent the views of the authors and not those of the Wharton School or the Pension Research Council. (C) 2013 Pension Research Council of the Wharton School of the University of Pennsylvania. All rights reserved. 


\title{
Contagious Runs in Money Market Funds and the Impact of a Government Guarantee
}

\begin{abstract}
$\underline{\text { Abstract }}$
Despite a vast theoretical literature on contagious behavior of investors, little is known about its empirical evidence in a real financial crisis setting. This paper examines evidence for contagious runs in money market funds during the 2008 financial crisis, drawing on a rich data set tracking U.S. money market funds' daily flows and their enrollment statuses in the Treasury Department's Temporary Guarantee Program (TGP). Evaluating the positive externality effect from a peer fund's enrollment in the TGP on non-enrolled funds, we show that panic-driven runs were contagious across funds. We find that funds' stability due to their enrollment in the guarantee program spilled over and enhanced daily flows to a non-enrolled fund by $\$ 1.8$ million compared to already-enrolled funds. Moreover, we find that retail investors were less likely than institutional investors to return to prime money market funds even after enrollment in the guarantee program, implying that the latter benefited more from the government back-stop. Results are germane to policies seeking to rebuild investor confidence in times of financial crises and reduce the chance of future contagion in this industry.
\end{abstract}

\section{Hugh Hoikwang Kim}

SKK Graduate School of Business

Sungkyunkwan (SKK) University

345 International Hall

25-2 Sungkyunkwan-ro

Seoul, Korea.

h.kim@skku.edu 


\section{Question and motivation}

During an epidemic outbreak, a contagious disease can be transmitted widely and may even lead to a severe pandemic if not properly contained. Similarly, financial shock can be contagious and can lead to a sudden collapse of a financial system. In a tightly intertwined financial system, there may be a high probability of such a systemic risk because a modest but contagious shock can be easily transmitted and amplified across players in the system, rapidly causing detrimental outcomes. Understanding the mechanism through which financial risk is transmitted in the financial system and identifying its empirical evidence are important steps in creating a robust financial market.

This paper provides the evidence for contagious runs in financial institutions, focusing on the U.S. money market funds during the 2008 financial crisis. The collapse of one of the biggest U.S. money market funds, the Reserve Primary Fund, on September 16, 2008 prompted a massive withdrawal from the U.S. prime money market fund industry. Within only three days, approximately $\$ 300$ billion was withdrawn from money market funds investing mainly in non-government securities. We show that the massive withdrawals were contagious across the money market funds.

As Diamond and Dybvig (1983) have noted in the banking sector, investors can generate a selffulfilling crisis because each investor wants to take his investment out earlier than his peers, when asset liquidation is costly. This mutually-reinforcing incentive of investors to take the same actions is often termed a "strategic complementarity" problem, and it can make otherwise healthy financial institutions insolvent. In addition, when financial institutions hold similar assets in their portfolios or in collateral pools while making collateralized loans 1 a massive withdrawal from one financial institution can propagate the risk of panicdriven runs to other financial institutions. This happens because investors in other financial institutions fear that a massive redemption request may trigger a fire sale of commonly held asset classes in the original financial institution, which in turn will generate subsequent distress for the market price of assets in another fund's portfolio. In this sense, a mutually reinforced process across groups of investors can lead to a systemic collapse of the financial market. Therefore, substantiating the existence of contagion in a real financial crisis setting sheds light on future policy about financial markets and institutions.

To date, however, there is little empirical evidence for the contagion risk of runs across financial institutions, despite the potential for such developments and their possible role in causing a systemic financial crisis. In a theoretical framework, Goldstein (2005) studied the strategic complementarities between two groups of investors - currency speculators and bank investors - as a mechanism to explain the observed

\footnotetext{
${ }^{1}$ Collateralized lending is a form of debt contract that requires a borrower to pledge asset or cash equivalents in return for cash, which the lender can liquidate should a borrower default. If the borrower pays back the debt, the asset is returned to the borrower.
} 
correlated frequency of banking and currency crises in emerging economies. In this paper, we develop and test several empirical hypotheses regarding the potential for contagious runs across money market funds, based on a stylized model of investor redemption behavior in a global game framework 2

Empirical identification of contagion risks is challenging because financial institution failures often occur in a short time-frame and with many unobservable factors (Allen, Babus and Carletti $(2010)$ ). For several reasons, money market funds in the U.S. provide an ideal setting to test the contagion risk of panic-driven runs in financial institutions. First, money market funds are not regulated as banks, but they issue securities that are very similar to demand-deposit contracts which are prone to panic-driven runs. Second, in 2008, the U.S. Treasury Department provided a Temporary Guarantee Program (TGP) similar to traditional bank deposit insurance. This confidence-building policy could serve to cut the chain of contagion across funds, which we can utilize to identify the contagion risk of runs. Third, a fund-sponsoring company usually has several money market funds, so we can observe investor behavior at both a fund and complex level.

To identify contagion risk of runs across funds, we use the U.S. Treasury's Temporary Guarantee Program (TGP) — an externally imposed stability measure — as a source of variation in contagion risk among money market funds. Specifically, we look at U.S. money market funds' daily flows during the first term of the TGP. This time period is significant because Lehman Brothers collapsed on September 15, creating a huge negative shock to the capital market and investors began to withdraw en masse from money market funds. On September 19, 2008, the U.S. Treasury Department offered the TGP, an unprecedented guarantee program to the entire money market mutual fund industry for the first time in its history. The guarantee program aimed to fix a coordination failure among investors and to avert investors' panic, which might have generated huge withdrawal requests from money market funds. Individual investors were not eligible to enroll in the TGP and funds that wished to be covered by this program were required to announce their enrollment and pay a premium of 1 to 2.5 basis points of assets under management as of September 19, $2008^{3}$ to the Treasury Department. To the extent that a contagion problem was a real possibility during the period following Lehman's collapse, the announcements that some funds had enrolled in the TGP likely had a positive spillover effect on other non-enrolled funds. This phenomenon is the flip side of contagious runs across funds. This is our main identification strategy for identifying the contagion risk of runs across funds. Because the announcement was made in a fund level, our identification strategy will enable us to identify

\footnotetext{
${ }^{2}$ The global game framework (Carlsson and Damme (1993) has been widely implemented in various areas of economics, including currency crises ((e.g., Morris and Shin (1998)) and bank runs (e.g., Goldstein and Pauzner (2005)).

${ }^{3}$ This premium was only for the first-term of the guarantee program, which lasted three months until December $18,2008$. This program was subsequently extended twice, until April 30, 2009 and then again until September 18, 2009. Funds were required to pay additional premiums if they wished to be covered during the extended periods.
} 
contagion risk of runs across funds.

Although enrollment status in the TGP is an attractive empirical identification tool, several challenging issues need to be addressed. The first is the adverse-selection issue related to signaling mechanism of enrollment announcement. Money market fund sponsors (for example, JP Morgan, Blackrock, Fidelity, and Vanguard) might have announced their enrollment in the guarantee program earlier or later based on their risk level. To validate our identification strategy to use a fund's enrollment status as an exogenous shock to its own and other funds' investors behavior, we run a simple test whether the enrollment timing was associated with funds' various characteristics including risk level and sponsor information. After analyzing the enrollment timing of funds in the TGP, we find that none of the funds' risk level (e.g., yield, portfolio composition) and sponsor information (e.g., bank-affiliated or not) were related to enrollment timing. The only factor in determining the enrollment status was investors-base information (i.e., retail or institutional investors funds). Benefiting from the richness of data on daily fund flows and enrollment status, we use the panel structure of data to control for fixed and persistent unobservable characteristics (i.e., investors-base information) of funds that might have affected enrollment status. Therefore, the adverse-selection or signaling mechanism might not have had much impact on our empirical findings as long as the unobservable factors are not changing in a daily frequency.

Second, there could have been many unobserved time-specific factors during the crisis, such as changes in short-term capital market conditions, shocks from other financial sectors, or even rumors. We overcome this issue using a time fixed effects model. Although a disadvantage of time fixed effects is that we cannot identify the effect of a time-trend on fund flows, the coefficients of interest about stability spillover effects are still identifiable using cross-sectional variation in funds' enrollment statuses. Data compiled from the Security and Exchange Commission's (SEC) disclosure system shows that fund sponsors did not all announce their TGP enrollments on the same date, which provides the opportunity to test for the existence of contagion risk of runs across money market funds.

The analysis shows that investors generated self-fulfilling runs across funds in the 2008 crisis. Our investigation of daily fund flows after the TGP was implemented reveals that funds experienced positive externalities from peer funds in other fund complexes having enrolled in the guarantee program. When funds enrolled in the guarantee program, which served to contain the contagion risk from those funds, other funds experienced decreased outflows even though they were not yet enrolled in the guarantee program $4^{4}$ The positive externality was more pronounced in non-enrolled funds than in those already-enrolled as expected. For example, each additional enrolled peer fund induced 4.1 basis points more daily inflows to non-enrolled

\footnotetext{
${ }^{4}$ The structure of the guarantee program eliminated the possibility of returning investors expecting more coverage. We discuss and negate alternative explanations for this fund flow pattern in section 6.3
} 
funds, compared to already-enrolled funds. A simple calculation implies that a fund with median asset size ( $\$ 4.7$ billion) on September 29,2008 , could have an extra $\$ 1.8$ million a day, due to the peer funds' stability.

To identify potential channel of contagion, we conduct the above analysis by assigning different weightings to peer funds' enrollment announcement. The idea is that investors might have expected greater positive externality from peer funds' stability, especially when those funds had greater contagion risk to their own funds and their TGP enrollment removed the contagion risk from them. We find that the enrollment of funds with more non-agency repurchase agreement (repo) transactions generated greater stability to other funds implying that investors worried about the risk of contagion through repo transaction channel (Gorton and Metrick (2012)) $!^{5}$

We also examine whether retail and institutional investors behaved differently once the TGP was in effect. We show that, in prime money market funds, institutional investors reinvested more actively compared to retail investors, after the introduction of the guarantee program. During the first term of the guarantee program (September 19-December 18, 2008), the total average daily fund flows to prime money market funds were 33 basis points higher, compared with during the Lehman crisis (September 15-19, 2008). By contrast, during that same guarantee period, retail investors withdrew by 34 basis points per day on average compared to the Lehman crisis period. This stark behavioral difference between retail and institutional investors is also observed in the second and third terms of the guarantee program (December 19, 2008-September 18, 2009). We also examine fund flows to government money market funds, which mainly held Treasury bills and government agency securities. We find little and statistically insignificant difference between retail and institutional investors' behaviors. Accordingly, the impact of the guarantee program was concentrated among institutional investors in prime money market funds. Retail investors did not return to prime money market funds, even after the guarantee program insured them against loss.

This study makes several contributions. First, it contributes to the literature on panicked investor runs and coordination problems in a financial crisis. Empirical evidence of coordination problems in a real financial crisis setting is relatively rare, compared to numerous theoretical papers in this literature. Chen, Goldstein and Jiang (2010) empirically substantiated the implication of strategic complementarity risk among investors by showing that illiquid equity funds experienced more outflows than liquid funds after bad performance. Our study demonstrates the existence and magnitude of strategic complementarity risk across groups of investors (that is, money market funds), focusing more on the systemic aspect of panicdriven runs. Although Goldstein (2005) studied this risk in a theoretical framework, it has not been tested in a real financial crisis setting despite its high potential for systemic crisis in the financial market.

\footnotetext{
${ }^{5}$ We also develop a model of contagion with this channel in the appendix.
} 
Second, this paper contributes to the literature on the effects of government stability-building measures such as deposit insurance. To the best of our knowledge, this is the first study that provides evidence on the existence and magnitude of the positive externality effects of such measures. In this paper, we examine the externality effects of peer financial institutions' enrollment in the TGP, which shares many features with traditional deposit insurance. Even though deposit insurance for banks has existed for eighty years in the United States, its actual impact has not been fully understood in an empirical setting. Most studies to date have focused on the problem of moral hazard (for example, Keeley $(1990)$ ), but the impact of government policy on averting investor panic has not been extensively studied in the literature. We fill this gap by demonstrating an additional aspect of stability-building measures - the positive externality effect across depository institutions.

Third, this paper contributes to the policy debate on systemic financial market regulations by documenting the existence and magnitude of systemic risk in a financial crisis. Concerns about systemic risk in the financial market were the rationale for the concept of market-wide regulation including the Dodd-Frank Act in the U.S. and macroprudential regulation in the E.U. (Borio (2003); Shin (2010)). Understanding the impact of U.S. government policy on money market funds in 2008 enables us to better assess the systemic risk of the investor coordination problem and to devise better government policy in future financial crises.

\section{Related literature}

The main economic hypothesis at the core of this paper is that investors can generate mutually reinforcing activities in the face of a financial shock, especially when coordination among investors is not possible. This is often discussed as one of the main causes for worsening the financial crisis, and the literature on this topic is extensive 6

This paper is directly related to the literature on the recent financial crisis and the shadow banking system, of which the money market fund industry is one very important component. Although the money market fund industry is the 5th largest financial sector in the U.S. 7 studies on these modern financial institutions are relatively scarce compared with the vast literature on traditional commercial banking. Among the few that studied the shadow banking sector, Krishnamurthy, Nagel and Orlov (2013) examined the size of collateralized lending contracts in money market funds and security lenders, and found that the AssetBacked Commercial Paper (ABCP) had first-order impacts on the capital market during the 2007-2008 crisis.

\footnotetext{
${ }^{6}$ For a thorough review on the recent financial crisis, see Allen, Babus and Carletti (2009) and Brunnermeier (2009).

${ }^{7}$ As of 2008 , U.S. commercial banks had $\$ 10.247$ trillion, open-end mutual funds had $\$ 5.435$ trillion, private pension funds had $\$ 4.552$ trillion, life insurers had $\$ 4.515$ trillion, and money market funds had $\$ 3.757$ trillion as their assets (FRB (2010).
} 
Gorton and Metrick (2012) highlighted the important role that repurchase agreement (repo) contracts played in exacerbating the financial crisis. Shleifer and Vishny (2010) showed that the shadow banking system is prone to swings in investor sentiment. Covitz, Liang and Suarez (2009) and Kacperczyk and Schnabl (2010), among others, provided empirical analyses of the ABCP market in the United States. These papers focused more on individual financial institutions rather than the systemic aspect of risk translation in the money market funds arena, which is the focus of our study.

Another body of literature related to this paper is the research on financial risk contagion. Our study provides empirical evidence of contagious fund runs in a real financial crisis. Focusing on the interbank lending market, Allen and Gale (2001) characterized structures that are prone to liquidity risk contagion. The liquidity risk was transmitted via direct lending-borrowing linkages. Iyer and Peydro (2011) found evidence for contagion risk via interbank linkages in India. Diamond and Rajan (2005) studied contagious bank failures via a liquidity shortage channel. Goldstein (2005) examined risk contagion between bank investors and currency speculators via the strategic complementarity problem. Benmelech and Dlugosz (2009) provided empirical evidence for the existence of a collateral channel for contagious bankruptcy in airline companies. Iyer and Puri (2012) found that a depositor was more likely to run on a bank when such behavior was observed in her social network such as neighborhood. 8

This paper is also related to a growing literature on money market funds. The additional contribution of this study is that we hand-collect the sequence of funds' enrollment in the TGP and use it as a tool to identify the contagious behavior of investors in a real financial crisis setting. Some recent papers (e.g., Kacperczyk and Schnabl (2013), Strahan and Tanyeri (2013) and Wermers (2010)) showed the importance of the Guarantee Program but from different angles. Wermers (2010) showed that institutional funds were run more than retail funds and that the withdrawers were likely to reinvest in government money market funds in the same fund complex during the early phase of the 2008 crisis. McCabe (2010) explored the cross-sectional relationships between fund outflows and three categories of risk (portfolio risk, investors risk, and sponsor risk). He found that funds with high yields, institutional investor-oriented, and risky sponsors, experienced more outflows during the September 7-October 8, 2008 period. Burcu Duygan-Bump (2013) focused on the effect of the Federal Reserve Boards' AMLF program (Asset-backed Commercial Paper Money Market Mutual Fund Liquidity Facility) on short-term lending markets. Chernenko and Sunderam (2012) showed that the European sovereign debt crisis in 2010 was transmitted to U.S. firms via money market funds. Kacperczyk and Schnabl (2013) investigated the risk-taking behavior of money market funds over the 2007-2010 period, and found that money market funds of sponsoring companies with high

${ }^{8}$ Other empirical studies on systemic financial risk include Adrian and Brunnermeier (2011); Boyson, Stahel and Stulz (2010); Jorion and Zhang (2009); and Iyer and Peydro (2011) among others. 
reputational concerns and limited resources took less risk after the asset-backed commercial paper crisis in 2007. Strahan and Tanyeri (2013) showed that money market funds did not take excessive risk after the TGP was implemented, contrary to the moral hazard effects. Our paper uses the TGP as an empirical identification tool to find the evidence for contagious runs across funds.

The literature on deposit insurance is also related to the present study. Our paper extends this literature by providing an additional aspect of deposit insurance - a positive externality effect across depository institutions. Earlier studies focused on banks' moral hazard problem. Keeley (1990) argued that deposit insurance enabled banks to take excessive risk, which exacerbated the moral hazard problem in the early 1980s when competition intensified in this industry. Demirguc-Kunt and Detragiache (2002) examined 61 countries in 1980-1997 and found a positive association between the existence of deposit insurance and a banking crisis. However, Iyer and Puri (2012) found deposit insurance effective in mitigating bank runs in the 2001 bank failure in India. Our study is providing an additional evidence for stabilizing effect of the government guarantee of deposit contract.

\section{Background information on money market funds and the 2008 crisis}

\subsection{Money market funds}

A money market fund 9 is a mutual fund that invests mainly in short-term credit market instruments such as Treasury securities, certificates of deposit (CDs), repurchase agreements (repo), or asset-backed commercial papers (ABCP). The first U.S. money market fund was created in the 1970s when the government imposed a cap on commercial bank deposit rates. Money market funds which had direct access to the credit market could provide higher yields than banks, and quickly gained popularity among both retail and institutional investors. At their peak in 2009, money market funds had $\$ 3.9$ trillion in total assets under management 10 According to the Investment Company Institute 1133 million American households owned money market funds in 2012 .

Money market funds are regulated by Rule 2a-7 under the Investment Company Act of 1940, which seeks to ensure that these funds do not take excessive risks in their investments. Although money market

\footnotetext{
${ }^{9} \mathrm{An}$ excellent source of information about money market instruments and money market funds is Stigum and Crescenzi 2007) and Investment Company Institute (ICI)'s archive: http://www.ici.org/mmfs.

${ }_{10}$ Total assets of commercial banks and mutual funds were $\$ 11.2$ trillion and $\$ 6.9$ trillion in 2008 according to the Federal Reserve Board's Flow of Funds.

11 (ICI):http://www.ici.org/mmfs.
} 
funds are not insured by the U.S. government, fund sponsors often provide support to their money market funds in times of trouble (Stigum and Crescenzi (2007)). For this reason, money market funds have been considered as a safe and liquid way to hold cash and earn returns that exceed bank rates.

\subsection{Lehman Brothers' bankruptcy in 2008 and "Breaking the Buck"}

Unlike other mutual funds, money market funds use an amortized accounting method when calculating their net asset value (NAV). Under this scheme, if the market value of a portfolio fluctuates within 0.5 cents per dollar, investors receive $\$ 1 \mathrm{NAV}$ when they redeem their investments. If the market value of a portfolio increases above $\$ 1$, a fund distributes the profits as dividends in order to make its NAV equal to $\$ 1$. If the market value of a portfolio falls below $\$ 0.995$, this is called "breaking the buck," and investors can redeem only the market value of their investments which is less than $\$ 1$ per share. This structure potentially allows investors to panic in withdrawing from funds, if they believe all other investors are going to withdraw and drive the NAV below $\$ 0.995$. Over the years, the investment industry has strenuously avoided such an outcome, and fund-sponsoring companies have provided financial support to ensure \$1 NAV (Stigum and Crescenzi (2007)).

Two cases of breaking the buck have occurred in the history of U.S. money market funds. The first happened in 1994, when Community Banker's U.S. Government Money Market Fund lost a large fraction of its investments in floating rate securities. Because that fund held long positions in interest-sensitive investments, the market value of its portfolio declined substantially when interest rates rose quickly in 1994 12 The second breaking-the-buck event happened in 2008, when the Reserve Primary Fund, one of the oldest money market funds in the United States, lost value due to its investment in unsecured debt issued by Lehman Brothers. When Lehman Brothers filed for bankruptcy on September 15, 2008, the Reserve Primary Fund had to report that its NAV fell below $\$ 0.995$. Within days, this fund faced massive redemption requests. Although its investors eventually recovered 99 cents per dollar after a long period of court adjustments, this event triggered market-wide redemptions from institutional funds mainly investing in non-government securities.

Facing severe price dislocations in the capital market, the U.S. government instituted several temporary programs to relieve distress in the money market fund industry. On September 19, 2008, the Treasury Department announced a Temporary Guarantee Program for money market funds and the FRB announced the Asset-backed Commercial Paper Money Market Mutual Fund Liquidity Facility (AMLF). The AMLF program provided collateralized loans to bank holding companies, which could buy asset-backed commercial

\footnotetext{
${ }^{12}$ ICI (http://www.ici.org/pdf/12_mmf_history.pdf).
} 
papers $(\mathrm{ABCP})$ from money market funds and use these securities as collateral to borrow from the Federal Reserve at no discount. Burcu Duygan-Bump (2013) showed that this program was effective in stabilizing the asset-backed commercial paper market.

\subsection{The U.S. Treasury Department's Temporary Guarantee Program (TGP)}

On September 19, 2008, the Treasury Department announced the "Temporary Guarantee Program for Money Market Funds." All money market funds registered with the Securities and Exchange Commission (SEC) and regulated under Rule 2a-7 of the Investment Company Act of 1940 were eligible for this temporary program 13 As the program was voluntary, money market funds seeking coverage had to apply and pay a premium between 1 and 2.5 basis points of total assets, depending on their portfolio value. Individual investors were not eligible to enroll. Enrollment decisions were made by each funds' board of directors and the announcement was made at the fund complex level. If an enrolled fund's net asset value dropped below $\$ 0.995$ (the Guarantee Event), the fund would have to liquidate its portfolio and the Treasury Department would indemnify the loss. The coverage of this program was predetermined by the closing balances on September 19, 2008. Any amount in excess of this limit was not covered; however, returning investors were covered up to their closing balance on September 19, 2008.

The initial term of the program lasted until December 18, 2008, but the Treasury Department later extended the program twice, the second term until April 30, 2009 and the third term until September 18, 200914 Enrollment in the second and third terms also was voluntary, but only funds that had enrolled in the first term coverage were eligible. For the program's first term, the application window was open from September 29, 2008 to October 8, 2008. Because enrollment in the Temporary Guarantee Program marked an important change in the fund's status, the SEC required each fund to announce its decision via a public disclosure system (SEC's EDGAR) 15 During the one-year period of the Temporary Guarantee Program, no money market fund broke the buck, and therefore, the Treasury Department did not have to pay any compensation.

\footnotetext{
${ }^{13} \mathrm{http}: / /$ www.treasury.gov/press-center/press-releases/Pages/hp1163.aspx

${ }^{14} \mathrm{http}: / /$ cranedata.com/archives/news/2008/12/\#item-2004

${ }^{15}$ According to our compilation of the disclosure documents (Form 497), almost all money market funds (except a handful of funds affiliated with the Reserve Fund and Lehman Brothers) enrolled in the Temporary Guarantee Program in the end.
} 


\section{Framework and hypotheses}

\subsection{Contagious Runs across Funds}

Money market funds are required to hold safe and liquid investments under Rule 2a-7 of the Investment Company Act of 1940, as noted above. A possible side effect of this rule is that many money market funds tend to end up with similar assets in their portfolios, which can be problematic during a time of market turmoil. One such asset class is asset-backed commercial paper, which was the reason that the Federal Reserve Board saw the need to provide a liquidity provision in this market (the AMLF program). Since the AMLF program targeted only one specific asset class, the possibility of contagion risk of runs remained via other asset classes such as non-agency repurchase agreement (repo) transactions or unsecured debt of nongovernment agencies. We found that mean correlation between funds' yields during the six-month period before the September 2008 crisis was 0.98 , which implies that the money market funds industry very likely was exposed to contagion risk through common asset holdings.

A panic-driven run on a fund can spread to other funds when investors develop fears about their own funds' investment linkages with the troubled funds. When financial institutions hold similar assets in their portfolios (or collateral pools when making collateralized loans), a massive withdrawal from one financial institution can propagate panic-driven runs to other financial institutions. This arises because investors in these other financial institutions fear that a massive redemption request in the original fund will trigger a fire sale of commonly held assets of the same class, which will generate subsequent distress in the portfolio's market price. Even when funds are not holding the exact same portfolio, a panic-driven run can spread to other funds because a small negative shock can move the market price of a share below $\$ 1$, in turn exacerbating the coordination problem within the fund. In other words, because peer investors' actions within the same fund or other funds can generate externality effects in their own investments, investors in the whole market are incentivized to herd in the same direction, that is, run on the funds. So strategic complementarity (that is, the reinforced incentive for investors to choose the same action because of peers' actions) can occur not only within one group of investors, but also across different groups of investors. This mechanism is developed more formally in Appendix A using the global game framework as in Goldstein (2005) and Goldstein and Pauzner (2005).

The Treasury Department's Temporary Guarantee Program provides an interesting setting in which to test for contagion risk across funds. Insofar as the guarantee program fixed a coordination failure issue, it eliminated the possibility of panic-driven runs on money market funds that had enrolled in the program. As there was time variation in funds' enrollment statuses over the period, we can analyze the impact of 
the Temporary Guarantee Program on peer funds' stability. We argue that, to the extent that contagion was a real concern during the crisis, an announcement that some other funds had enrolled in the guarantee program would have a positive spillover effect on non-enrolled funds.

We use the already-enrolled funds as a comparison group to measure the magnitude of the externality effect of additional peer funds' enrollment in the guarantee program. The positive externality effect would be more pronounced on non-enrolled funds than on already-enrolled funds, because already-enrolled funds were protected by their own insurance purchase, and peer funds' stability would not change the soundness of already-enrolled funds. In other words, the externality effect would be asymmetric based on funds' enrollment status in the guarantee program. This argument is summarized in the following:

Hypothesis 1: Peer funds' enrollment in the guarantee program had a greater positive externality impact on non-enrolled funds than on already-enrolled funds.

Because enrollment announcement was made at a fund complex level, this hypothesis is related to the contagion risk of runs across funds in different fund complexes. To highlight the intuition behind this hypothesis, assume that funds in a Fund Complex A enrolled in the guarantee program. This does not change the portfolio risk of funds in Fund Complex B, but it reduces Fund Complex B's exposure to contagion risk of fund run emanating from Fund Complex A. If there was contagion risk, then the enrollment announcement of Fund Complex A would have an externality effect on other funds. This effect is termed the "vaccine effect" in epidemiology, and it is a central problem in the efficient provision of public goods (Groves and Ledyard (1977); Bergstrom, Blume and Varian (1986)). Our identification strategy is discussed and implemented in Section 6.1.

\subsection{Comparison of Investors' Behavior: Retail vs. Institutional}

The mutual fund literature has documented that retail and institutional investors often behave differently. Sirri and Tufano (1998) showed that retail investors are more influenced by salient prior performance and the marketing efforts of mutual funds. Anagol and Kim (2012) found that retail investors were unlikely to pay proper attention to mutual funds' shrouded fees. Bordalo, Gennaioli and Shleifer (2012) proposed and experimentally verified a salience theory, in which decision makers put more weight on the most prominent states. Recent studies of money market funds (McCabe (2010), for example) also found that institutional investors responded more quickly to market conditions. Nevertheless, none of these studies explored how the Temporary Guarantee Program for mutual funds affected retail and institutional investors differently. 
Accordingly, we hypothesize that retail investors did not make full use of the Temporary Guarantee Program because they were influenced to a greater extent by bad news about the elevated risk of money market funds than by the government's stability measures. Focusing on the entire period during which the guarantee was offered (September 19, 2008 - September 18, 2009), we evaluate the following hypothesis:

Hypothesis 2: The Temporary Guarantee Program was used more extensively by institutional investors than by retail investors.

Testing this hypothesis provides important implications for policy measures in the financial market. If there was clientele bias in the implementation of government intervention, then it would be important to consider the distributional impacts of such an outcome. If retail investors were not savvy enough to quickly withdraw from funds at the forefront of the crisis, and they were slow to make use of the government-provided stability measures, there could have been cross-subsidization issues from retail to institutional investors.

\section{Data description}

The main sources of data are iMoneyNet, a data provider on money market funds, and the SEC's disclosure system (EDGAR). Fund characteristics and daily asset under management information were provided by iMoneyNet. The announcement date of each fund's enrollment in the Temporary Guarantee Program was hand-collected from the SEC EDGAR system (Form 497: Definitive materials) ${ }^{16}$ Money market funds are mainly categorized by their investor base (retail vs. institutional) and investment universe (government vs. nongovernment prime securities). The prime money market funds invest mainly in non-government, highly rated private securities, while government money market funds mainly invest in government-issued securities. The prime money market funds have constituted the largest category in the money market fund industry since the early 2000s, and total assets in prime money market funds reached almost $\$ 2.1$ trillion in September 2008. We focus on the prime money market funds with institutional and retail investors because these funds bore the investment risk that is essential to understanding investor behavior.

\footnotetext{
${ }^{16}$ A typical announcement had the following format taken from Bank of America's Columbia Money Market Funds: "The Board of Trustees of each of the money market funds listed above has approved and the Funds have applied for participation in the U.S. Treasury Department's Temporary Guarantee Program for Money Market Funds (the "Program") through December 18, 2008. Subject to certain conditions and limitations, share amounts held by investors in each of the Funds as of the close of business on September 19, 2008 are guaranteed against loss under the Program in the event the market-based net asset value per share is less than $\$ 0.995$ and a Fund subsequently liquidates. The Program only covers the amount a shareholder held in a Fund as of the close of business on September 19, 2008 or the amount a shareholder holds if and when a guarantee event occurs, whichever is less. The Program is subject to an overall limit of $\$ 50$ billion for all money market funds participating in the Program. The cost to participate in the initial three months of the Program will be borne by each Fund without regard to any expense limitation currently in effect for the Fund."
} 
The iMoneyNet data is two-stage stratified, in the sense that each fund complex has several funds and each fund has several share classes. Share class level information includes the fund's investor base (institutional or retail), expense ratio, asset size, and ticker symbol. Portfolio level information includes the fund's name, broad category of investment (for example, fraction of investment in Treasury bills, repo, time deposits, domestic/foreign bank obligations, floating rate notes, or asset-backed commercial paper), asset-weighted average maturity in weekly frequency, asset size, and gross yield. Fund complex level information includes the fund complex name, administrative information (fund complex contacts, custodian banks, domiciled state, manager information, redemption/purchase deadline), and bank affiliation if any.

We complement fund characteristics provided by iMoneyNet with information extracted from each fund's most recent quarterly disclosure forms prior to September 2008 (Form N-CSR, N-CSRS, N-Q). From the disclosure forms on portfolio holdings, we collect information about unsecured securities issued by Lehman Brothers held in each money fund, if any. We also collect information related to repo transactions such as principal amounts, interest rates, collateral types, and counterparties.

All variables are formally defined in Table 1. By examining the portfolio level asset size of each share class and its names, we can assign a unique portfolio identification code to share classes that were managed under the same funds or portfolio. We include only funds with assets of more than $\$ 1$ million because small funds can have highly volatile flows in relation to their asset size. We also exclude fund complexes with only one portfolio. Nevertheless, this criteria is more conservative than other papers using the money market fund data of iMoneyNet and so provide a more representative sample. We exclude the Reserve Funds and Lehman Brothers affiliated funds from the sample because those funds' stability was materially compromised after Lehman's collapse and the Reserve Primary Fund's breaking the buck 17 The final sample accounted for $93 \%$ ( $\$ 1.95$ trillion) of the total prime money market fund assets on September 2008.

\section{Table 1 here}

The average asset sizes of share classes and portfolios were $\$ 3.13$ billion and $\$ 13.64$ billion respectively over the period of September 15 - December 19, 2008. Immediately following Lehman Brothers' collapse on September 15, 2008, funds on average experienced investors' redemption by $12.4 \%$ of the total assets under management. About $27 \%$ of share classes were exposed to unsecured debt issued by Lehman Brothers, and $17 \%$ of share classes were exposed to repurchase agreements (repo) collateralized by non-government or non-agency securities. The average maturity of a portfolio was 45 days, and about $30 \%$ of assets were

\footnotetext{
${ }^{17}$ Including them only reinforced our result for the analysis of contagious runs within fund complexes, and we did not include them in the sample for analyzing contagious runs across funds because those were ineligible to apply for the Temporary Guarantee Program.
} 
maturing within seven days. On average, it took 12 days for fund complexes to announce their enrollment in the Temporary Guarantee Program once the application period began. About 52\% of share classes were for institutional investors, and about half of share classes were affiliated with bank sponsors.

\section{Empirical analysis}

In this section, we estimate an empirical model to test the hypotheses developed in the previous section. Section 6.1 investigates whether runs were contagious across funds (Hypothesis 1) by analyzing the impact of peer funds' Temporary Guarantee Program enrollment announcements during its first term (September 29-December 18, 2008). Section 6.2 describes the fund flows difference between institutional and retail share classes to test whether retail investors reinvested less in money market funds than institutional investors even after the government-provided stability measure became effective (Hypothesis 2).

\subsection{Hypothesis 1: contagion across funds}

The main empirical hypothesis (formally developed in Appendix A is that fund runs can be contagious across funds due to a strategic complementarity problem. We use the varying degrees of contagion risk across funds to examine for the possibility of contagious runs. The variation of enrollment status over time comes from the funds' announcement dates of enrollment in the TGP. Funds announced their enrollment individually but the announcement dates were usually same for all funds within a fund complex. As Figure 1 shows, some fund complexes announced their enrollment immediately after the opening day of application (September 29, 2008), but some funds waited until or after the deadline (October 8, 2008) to announce their enrollment 18

Figure 1here

We are interested in the impact of peer funds' enrollments in the Temporary Guarantee Program on a given fund's flow. To investigate the contagion risk of a panic-driven run, we hypothesize that the impact of peer funds' enrollment announcements in the TGP had a greater spillover effect on non-enrolled funds

\footnotetext{
${ }^{18}$ Reasons for the varying announcement dates might include differences in their decision making efficiency, inherent risk levels, or liquidity level of funds. More importantly, funds' unobservable characteristics (such as fund sponsors' willingness and ability to support their funds) might have affected the timing of their announcements. An analysis of enrollment decision and its impact on our identification are discussed in the following paragraphs.
} 
compared with already-enrolled funds. We specify the following empirical equation:

$$
\begin{aligned}
\text { Flow }_{f, c, t+1}= & \alpha+\gamma_{0} t+\sum_{\tau=0}^{2} \gamma_{1, \tau} \text { Enroll }_{c, t} \times S_{(-c), t-\tau}+\gamma_{2} \text { Enroll }_{c, t}+\sum_{\tau=0}^{2} \gamma_{3, \tau} S_{(-c), t-\tau} \\
& +\gamma_{4} \text { Flow }_{f, c, t}+\gamma_{5} \overline{F l o w}_{c(-f), t}+\gamma_{6} Y_{c}+\mu_{c, t}+u_{t}+\epsilon_{f, c, t+1},
\end{aligned}
$$

where the dependent variable llow $_{f, c, t+1}$ is the daily flow for fund $f$ in fund complex $c$ at time $t+1{ }^{19}$ The covariates include the following:20

- Enroll $l_{c, t}$ is an indicator variable equal to 1 if the fund complex c had announced it would enroll in the TGP as of $t$, and 0 otherwise;

- $S_{(-c), t}$ is a stability measure provided by peer funds at time $t$ due to their enrollment in the TGP. Enrollment of a fund with a higher level of contagion risk may provide more stability to its peers if its risk is contained by the guarantee program. Thus we use the weighted sum of enrolled peer funds as a stability measure. More specifically, the stability from peer funds due to their enrollment is characterized as a weighted sum of the number of enrolled fund complexes at $t$ as following

$$
S_{(-c), t} \equiv \sum_{k \neq c} \mathbf{1}_{\left\{t=\bar{t}_{k}\right\}} \times W_{k}
$$

where $\bar{t}_{k}$ is the announcement date of fund complex $k, \mathbf{1}_{\left\{t=\bar{t}_{k}\right\}}$ is equal to 1 is $t=\bar{t}_{k}$ and zero otherwise, and $W_{k}$ is the risk proxy of fund complex $k$ (for example, total asset size, number of share classes or portfolios within fund complexes, fund flow during the period September 15-19, 2008, number of portfolios that held Lehman securities or non-agency repos, yield correlations). Intuitively, $S_{(-c), t}$ signifies the eliminated contagion risk (i.e., additional stability) from peer funds, thanks to their enrollment in the guarantee program;

- $S_{(-c), t-\tau}$ is a lagged value of $S_{(-c), t}$. These additional terms are included to allow for the slow spread of news about peer funds' enrollment. We include lags of up to two days in the baseline model, but adding more lags did not change our result qualitatively ${ }^{21}$

- Flow $w_{f, c, t}$ is the own fund's lagged flows ${ }^{22}$

\footnotetext{
${ }^{19}$ The setting of the baseline model is similar to Papke (1994), which analyzed the effect of enterprise zones on unemployment and inventories, allowing the possible endogeneity issue of the enterprise zone designation.

${ }^{20}$ The data is two-stage stratified: The first strata is the fund complex level and the second is the fund level. In other words, one fund complex has several funds and each fund has several share classes. The main variation, the enrollment status, comes from the fund complex level. As Wooldridge (2002 highlighted, variation in the upper strata level can yield smaller standard deviation; therefore, we merged the share class level data (asset size) into the fund level data. The analysis with share class level data is qualitatively similar.

${ }^{21} \mathrm{An}$ analysis result with more lagged variables are presented in the Appendix C

${ }^{22}$ Other fund specific variables may include outflows right after Lehman's collapse, volatility of long-term flow, mean of long-
} 
- $\overline{F l o w}_{c(-f), t}$ is the average flows of peer funds in a fund complex $c$ defined as

$$
\frac{\sum_{k \neq c} T N A_{k, t}-\sum_{k \neq c} T N A_{k, t-1} \times\left(1+\text { Yield }_{k, t}\right)}{\sum_{k \neq c} T N A_{k, t-1}} \times 100,
$$

where $T N A_{k, t}$ is the total asset size of fund complex $k$ at time $t$;

- $Y_{c}$ includes fund complex-specific variables ${ }^{23}$ Because these variables do not change on a daily basis, they are eventually eliminated when we first-difference the baseline model;

- $\mu_{c, t}, u_{t}$ are unobserved complex-level and time-specific shocks, respectively;

- $\epsilon_{f, c, t}$ is an idiosyncratic shock to investors.

The coefficient of interest is $\left\{\gamma_{1, \tau}\right\}_{\tau=0}^{\tau=2}$. If the estimated $\gamma_{1, \tau}$ is negative, it implies that non-enrolled funds had greater externalities from peer funds' enrollment in the TGP compared with already enrolled funds. This means that investors of non-enrolled funds regarded the enrollment of peer funds in the guarantee program as a stabilizing action for their own funds, which is the parallel to the concern regarding contagious runs from peer funds.

The baseline assumption in an OLS setting would be that a fund complex's announcement of enrollment and peer funds' enrollment are exogenous to individual investors. This assumption seems innocuous because investors were not allowed to enroll individually in the guarantee program and fund complexes did not coordinate with each other to decide when to announce enrollment in the guarantee program. Moreover, an analysis of the enrollment timing in Table 2 reveals that funds' characteristics and portfolio allocations do not perfectly explain the enrollment announcement timing. This analysis shows that various fund complex characteristics, including asset size and portfolio allocations, are not jointly significant in explaining the number of business days taken for a fund complex to announce its enrollment in the guarantee program. The only variable that is significantly associated with the timing of the enrollment announcement is the investorbase variable; fund complexes catering more to retail investor ${ }^{24}$ were likely to announce their enrollments later than those oriented to institutional investors 25 Overall, the analysis result implies that investors could

term flow, and dummy variables for investor bases ( 1 if serving only retail investors, 2 if serving only institutional, 0 otherwise). Variables may also include portfolio composition (such as Treasury bills, repo transactions, or asset-backed commercial paper) as of $t$. Because we use a first-differenced model to eliminate unobservable shocks, all these time-invariant variables are dropped in the final estimation.

${ }^{23}$ For example, bank-affiliated fund sponsors and dummy variables for investor base.

${ }^{24}$ We defined retail-oriented fund complexes as those that had more than $50 \%$ of their total assets from retail investors over the last six months.

${ }^{25}$ This finding is consistent with the risk of investor base in explaining fund run (McCabe (2010)); market-sensitive investors are more prone to a panic-driven run. The fact that retail-oriented funds were more likely to announce later than institutionaloriented funds will cause an underestimation of the spillover effect of peer funds' enrollment in the guarantee program. Therefore, we get even stronger results for the spillover effect when we redo the analysis using only institutional-oriented fund complexes. See Table 5 
not guess accurately about funds' announcement timing based on observable characteristics.

Table 2

Even though the observable fund characteristics cannot explain the pattern of announcement timing, a challenging issue of identifying the asymmetric effects of peers' enrollment announcement is the possibility of self-selection bias; that is, fund companies were not randomly selected for enrollment in the Temporary Guarantee Program and fund complexes announced their enrollment based on their unobservable characteristics. We recognize that a fund's announcement (the status of enrollment, Enroll $l_{c, t}$ ) could have been influenced by unobservable complex-level shocks $\left(\mu_{c, t}\right)$ and time-specific shocks $\left(u_{t}\right)$, which econometricians cannot control (for example, fund sponsors' willingness or ability to support, expertise in risk management, or uncontrollable/unobservable events during the crisis). These factors will generate inconsistent estimates of $\left\{\gamma_{1, \tau}\right\}_{\tau=0}^{\tau=2}$ and allow alternative explanations of the fund flow patterns between enrolled and non-enrolled funds. For example, investors in non-enrolled funds could have reinvested in their original funds since their funds' delayed announcement might have sent a positive signal about the funds' (unobservable) stability and strength $\left(\mu_{c, t}\right)$. If that mechanism was the dominant force that generated the observed fund flow patterns, then we cannot conclude that the estimated coefficient $\left\{\gamma_{1, \tau}\right\}_{\tau=0}^{\tau=2}$ captures the externality effect of peer funds.

The panel structure of the daily fund flow data allows us to deal with the self-selection issue. If the complex-level shock $\mu_{c, t}$ is additively decomposable into a time-invariant complex level shock $\left(\omega_{c}\right)$ and a timespecific shock $\left(\delta_{t}\right)$, we can eliminate the time-invariant unobservable shocks by first-differencing the baseline model or including fund complex fixed effects ${ }^{26}$ If $\epsilon_{f, c, t}$ is serially uncorrelated, the fixed effect model with fund complexes, funds, and time dummies would be more efficient than the first-differenced model, but the high frequency of our data bodes well for the presence of serial correlation among error terms. Therefore, we first-difference the baseline empirical model and get the following regression specification:

$$
\begin{aligned}
\Delta \text { Flow }_{f, c, t+1}= & \gamma_{0}+\sum_{\tau=0}^{2} \gamma_{1, \tau} \Delta\left(\text { Enroll }_{c, t} \times S_{(-c), t-\tau}\right)+\gamma_{2} \Delta\left(\text { Enroll }_{c, t}\right)+\sum_{\tau=0}^{2} \gamma_{3, \tau} \Delta\left(S_{(-c), t-\tau}\right) \\
& +\gamma_{4} \Delta \text { Flow }_{f, c, t}+\Delta \zeta_{t}+\Delta \epsilon_{s, f, c, t+1}
\end{aligned}
$$

While first-differencing does not eliminate the time-specific shock $\left(u_{t}\right.$ and $\left.\delta_{t}\right)$. we can still consistently estimate $\gamma_{1, \tau}$ by introducing time fixed-effects $\left(\Delta \zeta_{t} \equiv \Delta \delta_{t}+\Delta u_{t}\right)$ to control for time-specific unobservable shocks because the main variable of interest has cross-sectional variation $\left(\operatorname{Enroll}_{c, t} \times S_{(-c), t-\tau}\right)$. The Gen-

\footnotetext{
${ }^{26}$ According to a technical survey study of Petersen (2009), this assumption of time-invariant firm specific shock is widely used in asset pricing and corporate finance literature.
} 
eralized Least Squares (GLS) method ${ }^{27}$ is used to estimate the model for efficiency gains in the face of a possible time-varying variance for the error term $\epsilon_{f, c, t}$ (Wooldridge (2002) ${ }^{28}$ We choose the first term of the Temporary Guarantee Program (September 29 - December 18, 2008) as our analysis period for testing Hypothesis 1 because the announcement of enrollment in the second and third terms of the TGP did not imply the same impact of enrollment to peer funds as the first term ${ }^{29}$

The testing result for Hypothesis 1 is presented in Table 3 with several different risk proxies (risk weighting $W_{c}$ ) used in the stability measure $S_{(-c), t}$ : (1) equal weighting for each enrolled fund complex; (2) fund outflows right after the Lehman's bankruptcy (September 15-19, 2008); (3) the number of portfolios that had nonsecured security issued by Lehman Brothers; (4) the log asset size of portfolios that had nonsecured securities issued by Lehman Brothers; (5) the number of portfolios that had non-agency repo transactions; (6) the log asset size of portfolios that had non-agency repo transactions; (7) the correlation between funds' gross yield for the past twelve months.

\section{Table 3 here}

The main coefficients of interest are $\left\{\gamma_{1, \tau}\right\}_{\tau=0}^{2}$, which measure the asymmetric externality of peers' stability on already-enrolled and non-enrolled funds. The negative coefficient of $\operatorname{Enroll}_{c, t} \times S_{(-c), t-\tau}$ implies that non-enrolled funds experienced a higher level of externality from peers' stability compared with alreadyenrolled funds.

This result supports Hypothesis 1 concerning contagious runs across funds: stability due to the TGP also spread across funds. Investors considered instability in peer funds in other fund complexes as a potential threat to themselves, and they also considered peer funds' increased stability based on their enrollment in the guarantee program as a stabilizing measure to themselves as well. More specifically, when the equal weighting of risk proxy is used (in column 1), non-enrolled funds experienced $0.041 \%$ higher daily inflows than already-enrolled funds, in response to peer funds' enrollment announcements two days prior. In column 2, when the outflow amount after Lehman's collapse is used as a risk proxy, the estimated coefficients of peers' contemporaneous, one-, and two-day lagged stability measures are all negative and statistically significant at

\footnotetext{
${ }^{27}$ In the GLS setting for estimation, we assumed intertemporary independent error structure, but assuming AR1 process also generated qualitatively and quantitatively similar results.

${ }^{28}$ The effect of the own fund flows may be biased in the order of inverse time period $\left(T^{-1}\right)$ because $F l_{f o w}, t$ is intertemporally correlated by construction. However, the bias may be minimal because our panel data has long time periods with large $T$ (Wooldridge (2002)). To check the robustness of the result, we use the lagged value of Flow $f, c, t-1$ as an instrumental variable for Flow $f, c, t$ based on the sequential exogeneity condition, and estimated the model with 2SLS with clustering in a fund complex level. The point estimates had very similar magnitudes and the same signs. But the estimated variances were slightly elevated, potentially because we could not control for time-varying variance of the error term.

${ }^{29}$ For example, even when Fund A did not announce its enrollment in the second term of the guarantee program during the last few weeks of the first term, it was still insured under the first term. However, we got qualitatively similar results with extended time periods of analysis.
} 
the $5 \%$ or $10 \%$ levels. In all specifications, the most pronounced effects are two-day lagged stability measures from peer funds enrollments in the guarantee program. This may be because news about peers' increased stability due to their enrollments in the guarantee program spread with delay or investors did not pay much attention to contemporaneous news about other funds in later stages of enrollment period 30

Additionally, the joint test of the impact of peer funds' enrollment status indicates that peers' stability had significant impacts on funds flows at the $5 \%$ or $10 \%$ level. We interpret this result as an indication that investors were less likely to withdraw from their own funds when funds in other fund complexes were less likely to experience investor runs. This mechanism also implies the positive externality effect of peers' stability, which this section substantiates.

The magnitude of the estimated externality effect of peer funds' stability is economically substantial, ranging from 0.5 to 4.5 basis points per day, depending on the choice of risk proxy and the lags on peer funds' announcements. For example, in column 1 where the equal weighting is used as a risk proxy, nonenrolled funds had more flows than already-enrolled funds by 4.1 basis points per day. Considering the median asset size of funds in the sample ( $\$ 4.48$ billion), non-enrolled funds had $\$ 1.8$ million more inflows than already-enrolled funds in the face of peers' stability because of enrollment in the guarantee program ${ }^{31}$

Figure 2 shows the asymmetric spillover effects to already-enrolled and non-enrolled funds. The pattern of average fund flow differences between already-enrolled and non-enrolled funds around peer funds' TGP enrollment announcements implies that the spillover effect of peer funds' stability was greater on nonenrolled funds than on already-enrolled funds. If the spillover effect of peer funds' stability was greater for non-enrolled funds, then the flow difference between enrolled and non-enrolled funds would narrow after peer funds' enrollment announcement in the guarantee program. This graph shows the change occured with a two-day lag.

Figure 2 here

\footnotetext{
${ }^{30}$ The speed of investors' reaction to peer funds stability is also related to the development stage of financial crisis. In Appendix $\bar{C}$ we show that investors were likely to act faster in the early phase of the crisis.

31 A-back-of-the-envelope calculation implies that this magnitude is 100 times greater than the charged insurance premium for the three month period. The median asset size of funds on September 19, 2008 was $\$ 4.72$ billion and the median asset size of funds on September 29, 2008 was $\$ 4.65$ billion. Assume a fund was charged 2.5 basis point of the remaining balance on September 19, 2008; then the premium charged was about $\$ 1$ million. If we assume the fund decided not to enroll in the guarantee program and there were additional peer fund enrollments every day for 60 business days during the first term, the estimated externality implies that an additional $\$ 104$ million flowed into a non-enrolled fund even though it was not enrolled in the guarantee program.
} 


\subsection{Hypothesis 2: comparison of institutional and retail investors behaviors}

In our previous analysis, we empirically substantiated the real chance of systemic risk and its magnitude; fund runs were contagious between funds, and the magnitude of the chance of systemic risk was substantial. This section describes our investigation of whether retail investors behaved differently from institutional investors. More precisely, we seek to compare retail and institutional investors' behaviors before and after the introduction of the Temporary Guarantee Program over the total period of the program (September 19, 2008 - September 18, 2009) ${ }^{32}$ Behavioral differences across investor types may have important implications for policy implementation, if clientele bias is related to the analysis of ultimate beneficiaries and cost-bearers of the policy.

The graph presented in Figure 3 shows the trend of assets under management of U.S. money market funds by categories of investment (prime vs. government) and investor base (retail vs. institutional). The vertical line indicates the date of Lehman's collapse (September 15, 2008). The upper panel shows that there was a "flight to quality" episode: investors withdrew from prime money market funds immediately after the Lehman shock and invested in government money market funds (Wermers (2010)). The lower left panel shows the stark difference between retail and institutional investors in prime money market funds. Even after the TGP was in effect, retail investors continued to withdraw from their funds. By contrast, institutional investors invested more. The lower right panel shows that institutional and retail investors of government money market funds behaved in a similar way when the guarantee program was effective.

To describe the behavioral differences quantitatively, we estimate the following empirical model for the entire period of the TGP (September 15, 2008-December 18, 2009):

$$
\text { Flow }_{s, f, c, t}=\beta_{0}+\sum_{\tau=2}^{5} \beta_{1, \tau}\left(I_{s, f, c} \times P_{t(\tau)}\right)+\beta_{2} I_{s, f, c}+\sum_{\tau=2}^{5} \beta_{3, \tau} P_{t(\tau)}+\beta_{4} X_{f, c, t}+\beta_{5} Y_{c}+u_{s, f, c, t}
$$

where the dependent variable Flow $_{s, f, c, t}$ is daily fund flows of share class $s$ in fund $f$ of fund complex $c$ at time

$t$ (defined as $\left.\frac{T N A_{f, c, t}-T N A_{f, c, t-1} \times\left(1+Y \text { ield }_{f, c, t}\right)}{T N A_{f, c, t-1}}\right) ; I_{s, c, f}$ is an indicator for the investor base (0: institutional, 1: retail); $P_{t(\tau)}$ is an indicator for time frame that is 1 if $t$ belongs to phase $\tau$ and zero otherwise; the phase $\tau$ is defined to be 1: for September 15-19, 2008; 2: for September 20-29, 2008; 3: for September 30-December 18, 2008; 4: for December 19, 2008-April 30, 2009; and 5: for May 1-December 18, 2009. In other words, Phase 1 represents the period of the Lehman crisis without any policy implementation; Phase 2 represents the introduction period of the TGP; Phase 3 represents the TGP's first term; Phase 4 represents the TGP's

\footnotetext{
${ }^{32}$ Recent studies on money market funds (including Wermers (2010, McCabe (2010), Burcu Duygan-Bump (2013) showed the behavioral difference between institutional and retail investors immediately following Lehman's collapse. We extended the analysis to the whole time frame of the Temporary Guarantee Program.
} 
second term; and Phase 5 represents the TGP's third term. $X_{f, c, t}$ includes fund portfolio information (or fixed effects) and $Y_{c}$ includes fund complex level variables (or fixed effects). The model is estimated with OLS regression.

We compare investor behavior in different time frames in Table 4. Columns 1-3 present behavioral differences between retail and institutional investors in prime money market funds, and columns 4-6 present the same analysis for government money market funds. Behavioral differences were substantial by investor and investment category after the Temporary Guarantee Program was effective. In prime money market funds, institutional investors reinvested actively after the introduction of the guarantee program. Column 1 indicates that total average daily fund flows to prime money market funds were 33 basis points higher, compared to the period of the Lehman crisis (Phase 1). By contrast, retail investors withdrew on average by 34 basis points in the same period compared to the Lehman crisis. In Phase 5 (the third term of the guarantee program), the difference was even starker. The total mean daily fund flow was 35 basis points, but retail investors withdrew by 39 basis points from prime money market funds. This finding indicates that most of the positive inflows to prime money market funds came from institutional investors during the guaranee program's third term.

\section{Table 4 here}

As a "placebo test" of investor behavioral differences in prime money market funds, we also examined fund flows to government money market funds, which were not negatively impacted by Lehman's bankruptcy. Columns 4-6 show there was little difference in behavior between institutional and retail investors in government money market funds. All interaction terms of investor indicator and periods were statistically insignificant.

In summary, our results indicate that the impact of the TGP was concentrated on institutional investors in prime money market funds. Retail investors did not return to prime money market funds even after the guarantee program insured them against loss.

\subsection{Alternative explanations}

\subsubsection{Expected enrollment}

One might argue that there was positive inflow into money market funds even before the funds actually enrolled in the guarantee program, because investors expected more benefits by investing early. An important feature of the guarantee program was that the coverage level was already determined as of the closing balance 
on September 19, 2008; any returning investors were guaranteed up to this level as long as the fund enrolled in the guarantee program. Additional investments beyond this guarantee limit were not insured even when a fund later enrolled in the guarantee program. Therefore, early comers took the risk of run and "breakingthe-buck" without additional coverage benefits. If there were no externality effect, investors would have been better off waiting for their own fund's announcement of enrollment in the guarantee program. Because the empirical analysis shows that investors reinvested earlier than their funds' actual enrollment dates, we can confirm that investors experienced stability effect from their peer funds due to the peer's enrollment in the guarantee program.

Even when an investor had fewer assets than the coverage limit by the time he decided whether to reinvest now or later, it was again better to wait until the fund actually enrolled in the program if there was no additional stability from enrolled peer funds. Early comers to non-enrolled funds had a small additional benefit of earning extra returns but the cost of facing the risk of "breaking-the-buck" before the fund's expected date of enrollment was huge. Because the fund was not yet covered, investors would have incurred a huge cost in a potential crisis ${ }^{33}$ And it was highly improbable that investors took this risk in exchange for small additional returns. Therefore, if there was no additional stability due to peer funds' enrollment, investors might have waited until their funds' actual enrollment in the guarantee program.

\subsubsection{Adverse-selection and the signaling effect of announcement}

An argument could be made that that non-enrollment in the guarantee program in the midst of others' enrollments would be a positive signal to an investor about his own funds' soundness. For example, if Fund A did not enroll in the guarantee program, then Fund B's announcement of enrollment might send a positive signal about Fund A's portfolio risk to investors, which could in turn increase inflows to Fund A. This concern is closely related to the endogeneity issues of enrollment decision and consequently to self-selection bias.

Nonetheless, our identification strategy is robust to the adverse-selection bias, as discussed in the empirical analysis (Section 6.1). The panel structure and relative high frequency of our data set allow us to eliminate unobservable fund complex level characteristics that might have affected both fund flows and enrollment status in the TGP. In addition, we showed that the funds' risk level proxied by portfolio information was not correlated with the enrollment timing and the time-invariant investor-base information (i.e., retail or institutional investors) was the only significant factor affecting the enrollment status over time (see Table 2). Therefore, the signaling mechanism is not likely to bias our empirical results.

\footnotetext{
${ }^{33}$ Investors of Reserve Primary Fund had to wait for three years to recover 99 cents for every dollar investment until the court adjustment was completed.
} 


\subsubsection{Confounding effect of the Asset-backed Commercial Paper Money Market Mutual Fund Liquidity Facility (AMLF)}

On the same day that the Treasury Department announced the Temporary Guarantee Program, the Federal Reserve Bank of Boston (FRBB) announced a liquidity facility program called the Asset-backed Commercial Paper Money Market Mutual Fund Liquidity Facility (AMLF). Since this program enabled banks to borrow cash using the purchased $\mathrm{ABCP}$ as collateral, money market funds could sell their $\mathrm{ABCP}$ to banks with no discount.

The design of this program and the flow of loaned amounts over the analysis period shows that the AMLF program could not have had much impact on our identification strategy. According to FRB data, the amount of loaned cash under the AMLF program peaked right after the introduction of the program, but it promptly declined after money market funds began to announce their enrollment in the Temporary Guarantee Program (refer to Figure 4). This implies that the effect of the Temporary Guarantee Program quickly overwhelmed the effect of AMLF, and consequently, our results are not driven by the AMLF program. In some sense, the AMLF program was substituted by the TGP in terms of staunching fund outflows.

Moreover, the market-wide impact of the AMLF could have been controlled in our empirical analysis setting. Benefiting from the richness of data on daily fund flows and enrollment status, we use the crosssectional variation of enrollments across funds as our main source of identification. Considering the fact that the AMLF program was barely used by funds after the TGP was implemented, any residual impact it might have had on the overall capital market could have been controlled by the time fixed effects.

Figure 4 here

\section{Implications for potential policy reform}

Our study sheds light on current debates about U.S. money market fund reforms and the shadow banking system ${ }^{34}$ in general. In 2010, the SEC implemented reforms that may reduce the risk of future runs ${ }^{35}$ But based on the premise that money market funds are still prone to market-wide panic, some U.S. regulators have sought to impose more stringent regulation on the money market fund industry. Debate has continued

\footnotetext{
${ }^{34}$ The term "shadow banking system" refers to financial entities that engage in financial transactions but are less heavily regulated than banks; it also is sometimes called the "securitized banking system" Gorton and Metrick (2012) Examples of institutions in this arena include money market funds, private equity and hedge funds, monoline insurers, and other securities operators.

${ }^{35}$ Since 2010, money market funds are required to disclose their portfolio holdings every month and shorten the weighted average maturity. They are also required to hold $10 \%$ of its assets in cash or securities which can be liquidated in one day. Source: ICI (http://www.ici.org/pdf/12_mmf_2010_reforms_jul.pdf)
} 
since 2008, and came to a head in the second quarter of 2012 when U.S. Security and Exchange Commission (SEC) Chairperson Mary Schapiro stated, "This industry and regulators are living on borrowed time . . . Funds remain vulnerable to the reality that a single money market fund breaking of the buck could trigger a broad and destabilizing run. ${ }^{36}$ Federal Reserve Board (FRB) Chairperson Ben Bernanke (2012) noted that the financial crisis occurred and was amplified by a number of vulnerabilities outside the traditional banking sector (that is, the "shadow banking system"), including money market funds. Even though the SEC instituted money market fund reforms in 2010 , the agency is considering whether to require money market funds to eliminate the fixed $\$ 1$ net asset value (NAV) scheme and have an extra capital buffer based on the assumption that these rules will dispose of future market-wide panics. Yet the money market fund industry is challenging regulators' concerns about the funds' stability and their exposure to system-wide risk. The industry contends that these new rules will change the fundamental structure of money market funds and that they will not be accepted by the majority of investors, including corporate treasurers and institutional investors. This, it has been argued 37 would damage a key channel for short-term liquidity for corporations. After a long debate with the money market fund industry, SEC Chairperson Mary Schapiro abandoned her plan to propose additional regulation in August, 2012 calling instead for more research in the money market funds industry. In this section, we evaluate several policy options to mitigate the contagion risk of runs in money market funds industry.

\subsection{Monitoring the interlinkages of portfolio and collateral}

If one asset class is considered safe and liquid, it will be widely used in the capital market as collateral or for direct investment. This study's results show that the chances of a run on depository institutions can be transferred and amplified through the interlinkages of collaterals or portfolios. One unrealistic solution would be to require every financial institution to have different asset classes in their portfolios and collateral holdings to mitigate the problem of risk contagion and systemic risk. In contrast, a more realistic solution would be to implement a thorough monitoring system on the quality and interlinkages of financial institutions' asset holdings. Regulators could monitor the quality and interconnectedness of collateral before asset classes believed to be safe and liquid turn out to be low quality or illiquid assets.

\footnotetext{
${ }^{36}$ The Wall Street Journal (April 26, 2012): Money Funds' Battle Royal.

${ }^{37}$ ICI (http://www.ici.org/pressroom/news/12_news_tsi_study)
} 


\subsection{Fixed or floating net asset value schemes}

When a fund's net asset value is fixed at $\$ 1$ per share, even a small divergence of the share's market value from $\$ 1$ can generate a strategic complementarity problem among investors. If the underlying asset value falls below $\$ 1$ and early withdrawers redeem at $\$ 1$ per share, money market funds must sell more shares than the initial amount of shares early withdrawers had. All investors will find it optimal to run on the funds, even though the fundamental portfolios might be sufficiently sound in the long run.

If the net asset value fluctuates according to the fund's portfolio market value, and early withdrawers can only redeem the market value of shares, money market funds would sell the exact number of shares that the early withdrawer owned. This way, the early withdrawers would not impose a negative externality on other peer investors. Thus, the floating net net asset value scheme would be less prone to a self-fulfilling run.

Although the floating net asset value scheme can mitigate the panic problem, it may nevertheless impose large accounting costs on fund investors (as argued by the money market fund industry and customer ${ }^{38}$. An important question beyond the scope of this paper is whether the costs of a floating NAV (accounting cost) exceeds their benefits (avoiding a self-fulfilling run).

\subsection{Confidence building measures}

When the risk of a fund run is due to panic-driven reasons, confidence-building measures are likely to be effective at low cost (Dybvig and Spatt (1983)). The Treasury Department's Temporary Guarantee Program did not pay any indemnification and collected premiums of $\$ 1.2$ billion ${ }^{39}$ from fund companies because no claim was made. If investor panic is horizontally contagious across financial institutions, insurance can provide an even higher level of stability with similar costs, compared to the case of no contagion risk.

When moral hazard is well controlled, implementing an insurance scheme in the money market fund industry can be a solution to preventing future disastrous runs. As this study's results show, a panic-driven run due to strategic complementarity risk can be contagious across financial institutions and may become a catastrophe in a financial system. Accordingly, a financial regulatory authority can serve as a coordinator in controlling the strategic risk at a low cost. An analysis by Strahan and Tanyeri (2013) shows that money market funds did not take much risk after the TGP was implemented, contrary to the moral hazard effects.

Based on our results, one potential concern may be the possibility of a free-rider problem. When there is a systemic risk and stability-building measures are established in some financial institutions, other

\footnotetext{
${ }^{38}$ source: http://www.preservemoneymarketfunds.org

${ }^{39}$ SEC (http://www.sec.gov/comments/4-619/4619-49.pdf)
} 
institutions may seek to underinvest in controlling risk (that is, purchasing insurance) since they can benefit from positive externalities from peer institutions. This free-rider problem is more pronounced when the institutions are not mandated to enroll in the insurance and are charged a high premium. Therefore, if an insurance scheme were introduced for money market funds, mandating enrollment would help mitigate the free-rider problem.

\section{Conclusions}

This study shows that panic-driven runs were contagious in the U.S. money market fund industry in 2008. Using a rich data set on money market funds daily flows and the Temporary Guarantee Program by the Treasury Department, we find that investors generated self-fulfilling runs across funds. Our findings suggest that panic among investors is not only an individual financial institution's problem, but also a potentially system-wide problem in a financial market.

The way we identify the contagion risk across funds also illuminates an interesting aspect of the government's confidence-building measures such as deposit insurance in a financial system. In our empirical setting, funds' enrollment in the Treasury Department's guarantee program had a positive spillover effect on other funds. As the run risk was contagious, stability also spread across the funds when the government's confidence-building policy averted investors' panic. This suggests that a potential free-rider problem may need to be addressed when implementing confidence-building measures in the financial market (e.g., deposit insurance).

We also document that institutional and retail investors behaved differently after the introduction of the government guarantee program. Retail investors did not return to money market funds investing in non-government securities, even though the government provided an unprecedented guarantee program. By contrast, institutional investors returned en masse to the money market funds. This behavior suggests that more sophisticated institutional investors might have been the main beneficiaries of the policy, even though the insurance premium structure did not differ across investor types. 


\section{References}

Adrian, Tobias, and Markus K. Brunnermeier. 2011. "CoVaR." National Bureau of Economic Research Working Paper 17454.

Allen, Franklin, Ana Babus, and Elena Carletti. 2009. "Financial Crises: Theory and Evidence." Annual Review of Financial Economics, 1: 97-116.

Allen, Franklin, Ana Babus, and Elena Carletti. 2010. "Financial Connections and Systemic Risk." National Bureau of Economic Research Working Paper 16177.

Allen, Franklin, and Douglas Gale. 2001. "Financial Contagion." Journal of Political Economy, 108(1): 1-33.

Anagol, Santosh, and Hugh Hoikwang Kim. 2012. "The Impact of Shrouded Fees: Evidence from a Natural Experiment in the Indian Mutual Funds Market." American Economic Review, 102(1): 576-93.

Benmelech, Efraim, and Jennifer Dlugosz. 2009. "The Credit Rating Crisis." National Bureau of Economic Research Working Paper 15045.

Bergstrom, Theodore, Lawrence Blume, and Hal Varian. 1986. "On the Private Provision of Public Goods." Journal of Public Economics, 29: 25-49.

Bernanke, Ben S. 2012. "Some Reflections on the Crisis and the Policy Response." speech at the Russell Sage Foundation and The Century Foundation Conference on "Rethinking Finance," New York, New York.

Bordalo, Pedro, Nicola Gennaioli, and Andrei Shleifer. 2012. "Salience Theory of Choice Under Risk." The Quarterly Journal of Economics, 127(3): 1243-1285.

Borio, Claudio. 2003. "Towards a Macroprudential Framework for Financial Supervision and Regulation?" Bank for International Settlement (BIS). BIS Working Papers No 128.

Boyson, Nicole M., Christof W. Stahel, and Rene M. Stulz. 2010. "Hedge Fund Contagion and Liquidity Shocks." The Journal of Finance, 65(5): 1789-1816.

Brunnermeier, Markus K. 2009. "Deciphering the Liquidity and Credit Crunch 2007-2008." Journal of Economic Perspectives, 23(1): 77-100.

Burcu Duygan-Bump, Patrick M. Parkinson, Eric S. Rosengren Gustavo A. Suarez Paul S. Willen. 2013. "How Effective Were the Federal Reserve Emergency Liquidity Facilities? Evidence 
from The Asset-backed Commercial Paper Money Market Mutual Fund Liquidity Facility." The Journal of Finance, 68(2): 715-737.

Carlsson, Hans, and Eric van Damme. 1993. "Global Games and Equilibrium Selection." Econometrica, 61(5): pp. 989-1018.

Chen, Qi, Itay Goldstein, and Wei Jiang. 2010. "Payoff Complementarities and Financial Fragility: Evidence from Mutual Fund Outflows." Journal of Financial Economics, 97(2): 239 - 262.

Chernenko, Sergey, and Adi Sunderam. 2012. "The Quiet Run of 2011: Money Market Funds and the European Debt Crisis." OSU and Harvard University, Fisher College of Business Working Paper No. $2012-4$.

Cifuentes, Rodrigo, Gianluigi Ferrucci, and Hyun Song Shin. 2005. "Liquidity Risk and Contagion." Journal of the European Economic Association, 3(2-3): 556-566.

Covitz, Daniel M., Nellie Liang, and Gustavo A. Suarez. 2009. "The Evolution of a Financial Crisis: Panic in the Asset-Backed Commercial Paper Market." Federal Reserve Board, Washington, D.C.

Demirguc-Kunt, Asli, and Enrica Detragiache. 2002. "Does Deposit Insurance Increase Banking System Stability? An Empirical Investigation.” Journal of Monetary Economics, 49: 1373-1406.

Diamond, Douglas W., and Philip H. Dybvig. 1983. "Bank Runs, Deposit Insurance, and Liquidity." Journal of Political Economy, 91(3): pp. 401-419.

Diamond, Douglas W., and Raghuram G. Rajan. 2005. "Liquidity Shortages and Banking Crises." The Journal of Finance, 60(2): 615-647.

Dybvig, Philip H., and Chester S. Spatt. 1983. "Adoption externalities as public goods." Journal of Public Economics, 20(2): $231-247$.

FRB. 2010. "Flow of Funds Accounts of the United States." Federal Reserve Board.

Goldstein, Itay. 2005. "Strategic Complementarities and the Twin Crises." The Economic Journal, 115(503): 368-390.

Goldstein, Itay, and Ady Pauzner. 2005. "Demand-Deposit Contracts and the Probability of Bank Runs." Journal of Finance, 60(3): 1293-1327.

Gorton, Gary, and Andrew Metrick. 2012. "Securitized banking and the run on repo." Journal of Financial Economics, 104(3): 425 - 451. 
Groves, Theodore, and John Ledyard. 1977. "Optimal Allocation of Public Goods: A Solution to the "Free Rider" Problem." Econometrica, 45: 783-810.

Iyer, Rajkamal, and Jose-Luis Peydro. 2011. "Interbank Contagion at Work: Evidence from a Natural Experiment." Review of Financial Studies, 24(4): 1337-1377.

Iyer, Rajkamal, and Manju Puri. 2012. "Understanding Bank Runs: The Importance of Depositor-Bank Relationships and Networks." American Economic Review, 102(4): 1414-1445.

Jorion, Philippe, and Gaiyan Zhang. 2009. "Credit Contagion from Counterparty Risk." The Journal of Finance, 64(5): 2053-2087.

Kacperczyk, Marcin, and Philipp Schnabl. 2010. "When Safe Proved Risky: Commercial Paper during the Financial Crisis of 2007-2009." Journal of Economic Perspectives, 24(1): 29-50.

Kacperczyk, Marcin, and Philipp Schnabl. 2013. "How Safe are Money Market Funds?" Quarterly Journal of Economics, Forthcoming.

Keeley, Michael C. 1990. "Deposit Insurance, Risk, and Market Power in Banking." American Economic Review, 80(5): 1183-1200.

Krishnamurthy, Arvind, Stefan Nagel, and Dmitry Orlov. 2013. "Sizing Up Repo." The Journal of Finance, Forthcoming.

Manski, Charles F. 1993. "Identification of Endogenous Social Effects: The Reflection Problem." The Review of Economic Studies, 60(3): pp. 531-542.

McCabe, Patrick E. 2010. "The Cross Section of Money Market Fund Risks and Financial Crises." Federal Reserve Board, Finance and Economics Discussion Series 2010-51.

Morris, Stephen, and Hyun Song Shin. 1998. "Unique Equilibrium in a Model of Self-Fulfilling Currency Attacks." The American Economic Review, 88(3): pp. 587-597.

Morris, Stephen, and Hyun Song Shin. 2000. "Global Games: Theory and Applications." Cowles Foundation for Research in Economics, Yale University Cowles Foundation Discussion Papers 1275.

Morris, Stephen, and Hyun Song Shin. 2004. "Coordination Risk and the Price of Debt." European Economic Review, 48(1): 133 - 153.

Papke, Leslie E. 1994. "Tax Policy and Urban Development: Evidence from the Indiana Enterprise Zone Program." Journal of Public Economics, 54(1): 37 - 49. 
Petersen, Mitchell A. 2009. "Estimating Standard Errors in Finance Panel Data Sets: Comparing Approaches." Review of Financial Studies, 22(1): 435-480.

Shin, Hyun Song. 2010. "Macroprudential Policies Beyond Basel III." Princeton University, Policy Memo.

Shleifer, Andrei, and Robert W. Vishny. 2010. "Unstable Banking." Journal of Financial Economics, $97(3): 306-318$.

Sirri, Erik R., and Peter Tufano. 1998. "Costly Search and Mutual Fund Flows." The Journal of Finance, 53(5): 1589-1622.

Stigum, Marcia, and Anthony Crescenzi. 2007. Stigum's Money Market. New York: McGraw-Hill.

Strahan, Philip E., and Basak Tanyeri. 2013. "Once Burned, Twice Shy? Money Market Fund Responses to a Systemic Liquidity Shock." Journal of Financial and Quantitative Analysis, Forthcoming.

Thomson-Reuters. 2012. "Thomson Reuters CDS."

Wermers, Russ. 2010. "Money Fund Runs." Unpublished working paper, University of Maryland.

Wooldridge, Jeffrey M. 2002. Econometric Analysis of Cross Section and Panel Data. MIT Press. 
Table 1: Variable definitions

Including only fund complexes with more than two money market funds, we have 43 fund complexes and 170 unique funds for each daily observation. The sample period is the first term of the Temporary Guarantee Program (TGP), September 19, 2008 December 18, 2008. The total number of observations (fund $\times$ time) varies depending on the analysis period and can be found at the end of each regression table.

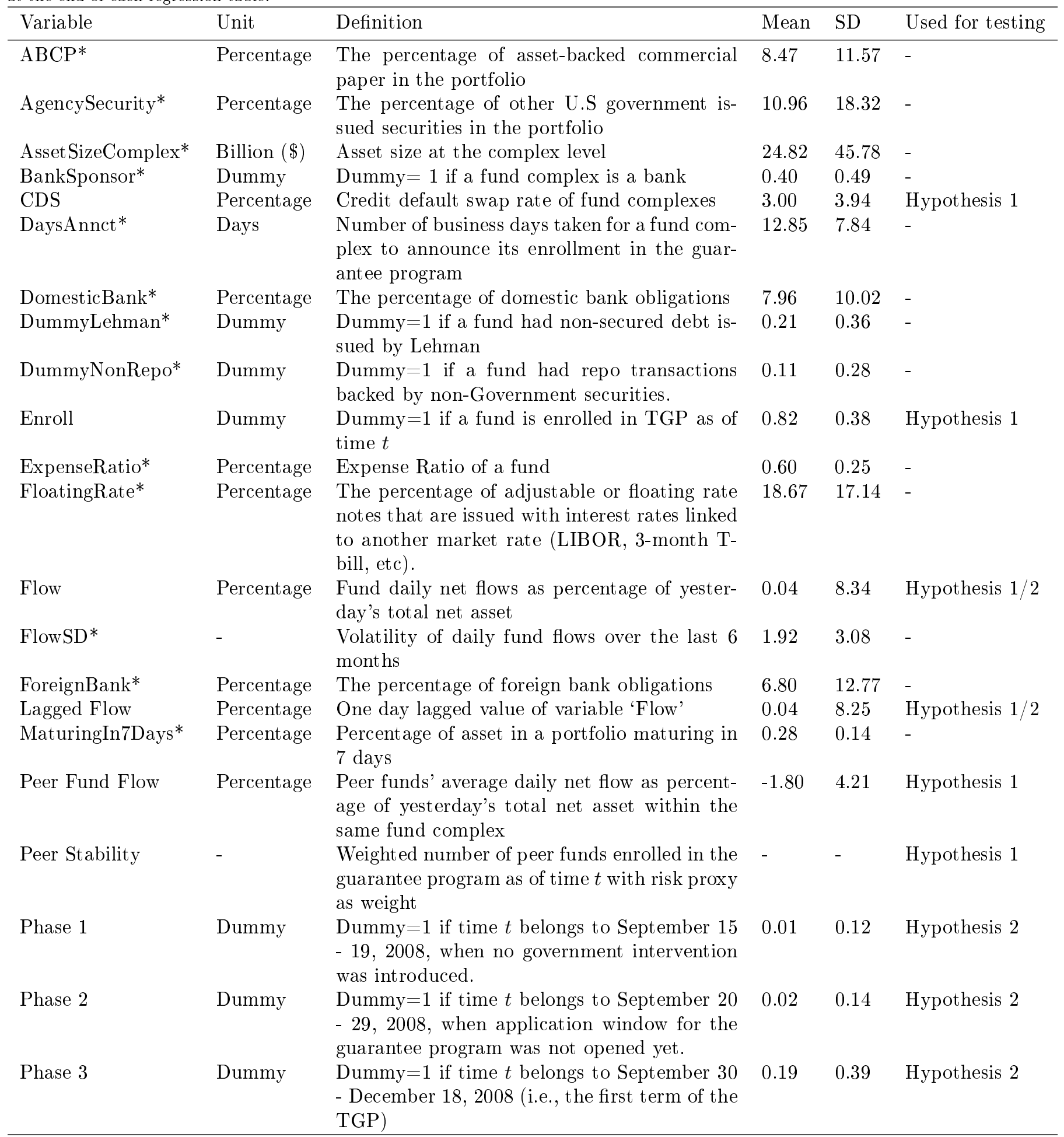


Table 1 - continued

\begin{tabular}{|c|c|c|c|c|c|}
\hline Variable & Unit & Definition & Mean & SD & Used for testing \\
\hline Phase 4 & Dummy & $\begin{array}{l}\text { Dummy }=1 \text { if time } t \text { belongs to December } 19 \text {, } \\
2008 \text { - April } 30,2009 \text { (i.e., the second term of } \\
\text { the TGP) }\end{array}$ & 0.29 & 0.45 & Hypothesis 2 \\
\hline Phase 5 & Dummy & $\begin{array}{l}\text { Dummy }=1 \text { if time } t \text { belongs to May } 1- \\
\text { September } 18,2009 \text { (i.e., the third term of the } \\
\text { TGP) }\end{array}$ & 0.49 & 0.50 & Hypothesis 2 \\
\hline Proxy 1 & - & unit measure & 1 & 0 & Hypothesis 1 \\
\hline Proxy 2 & Percentage & $\begin{array}{l}\text { Fund flow in a complex level right after } \\
\text { Lehman's bankrupcy }(9 / 15-9 / 19 / 2008)\end{array}$ & -8.31 & 12.66 & Hypothesis 1 \\
\hline Proxy 3 & - & $\begin{array}{l}\text { Number of portfolios in a fund complex with } \\
\text { non-secured debt issued by Lehman Brothers. }\end{array}$ & 1.13 & 0.66 & Hypothesis 1 \\
\hline Proxy 4 & - & $\begin{array}{l}\text { Log of asset size of portfolios (\$billion) in a } \\
\text { fund complex with non-secured debt issued by } \\
\text { Lehman Brothers. }\end{array}$ & 1.05 & 0.84 & Hypothesis 1 \\
\hline Proxy 5 & - & $\begin{array}{l}\text { Number of portfolios in a fund complex } \\
\text { with repo transactions collateralized by non- } \\
\text { Government agency security }\end{array}$ & 1.15 & 0.77 & Hypothesis 1 \\
\hline Proxy 6 & - & $\begin{array}{l}\text { Log of asset size of portfolios (\$billion) in a } \\
\text { fund complex with repo transactions collater- } \\
\text { alized by non-Government agency security }\end{array}$ & 1.23 & 0.84 & Hypothesis 1 \\
\hline Proxy 7 & - & $\begin{array}{l}\text { Correlation between funds' gross yield for the } \\
\text { past } 12 \text { months }\end{array}$ & 0.98 & 0.11 & Hypothesis 1 \\
\hline Repo* & Percentage & $\begin{array}{l}\text { The percentage of assets invested in repur- } \\
\text { chase agreement transactions }\end{array}$ & 10.68 & 12.61 & - \\
\hline Retail & Dummy & Dummy $=1$ if a shareclass is for retail investors & 0.52 & 0.50 & Hypothesis 2 \\
\hline RetailOriented* & Dummy & $\begin{array}{l}\text { Dummy }=1 \text { if a fund complex had more than } \\
50 \% \text { assets from retail investors }\end{array}$ & 0.49 & 0.50 & - \\
\hline TimeDeposit* & Percentage & $\begin{array}{l}\text { Negotiable certificates of deposit (CDs) and } \\
\text { banker's acceptance (BAs) that are first tier } \\
\text { or second tier securities, as defined by the SEC }\end{array}$ & 1.34 & 2.86 & - \\
\hline TripleA* & Dummy & $\begin{array}{l}\text { Dummy }=1 \text { if a fund is rated as AAA by rating } \\
\text { agencies. }\end{array}$ & 0.30 & 0.37 & - \\
\hline UsTreasury & Percentage & $\begin{array}{l}\text { The percentage of assets invested in U.S. gov- } \\
\text { ernment securities }\end{array}$ & 0.82 & 4.35 & - \\
\hline VIX & - & $\begin{array}{l}\text { Measure of market volatility based on S \& P } \\
500\end{array}$ & 33.78 & 1.79 & - \\
\hline WeightedMaturity & Days & Weighted average maturity & 43.78 & 10.50 & - \\
\hline Yield & Percentage & Annualized gross yield before expense & 1.15 & 0.89 & Hypothesis 2 \\
\hline
\end{tabular}

Note: * indicates variables that are used to analyze enrollment status at a fund complex level. These variables were averaged at a fund complex level over six months (March 15-September 15, 2008). Some variable definitions are quoted directly from the data provider's explanations. 
Table 2: Determinants of timing of fund complexes' announcement of enrollment in the TGP

This table presents the effect of several variables on the timing of fund complexes' announcement of enrollment in the Temporary Guarantee Program (TGP). The dependent variable is the number of business days taken for a fund complex to announce its enrollment in the guarantee program. Independent variables include asset size, standard deviation of daily flows at the complex-level, credit ratings, gross return, expense ratio, the dummy variable for Lehman Brothers security, dummy variables for non-agency repo, and portfolio allocations. All variables are averaged over six months (March 15-September 15, 2008). To provide a more complete analysis of enrollment timing of fund complexes, we include all fund complexes including those with only one money market funds. This is why we have 75 fund complexes here unlike the hypotheses testings. The analysis results show that retail-oriented fund complexes were more likely to announce their enrollment later than institutional-oriented fund complexes. As the joint test result shows, other observable characteristics of fund complexes do not explain the announcement timings.

\begin{tabular}{|c|c|c|c|c|}
\hline & (1) & (2) & (3) & (4) \\
\hline FlowSD & $\begin{array}{c}-0.129 \\
(0.17)\end{array}$ & $\begin{array}{l}-0.112 \\
(0.17)\end{array}$ & $\begin{array}{c}-0.103 \\
(0.18)\end{array}$ & $\begin{array}{l}-0.039 \\
(0.17)\end{array}$ \\
\hline RetailOriented & $\begin{array}{l}4.418^{* *} \\
(1.77)\end{array}$ & $\begin{array}{l}4.858^{* *} \\
(2.00)\end{array}$ & $\begin{array}{l}4.435^{* *} \\
(2.12)\end{array}$ & $\begin{array}{l}4.312^{*} \\
(2.35)\end{array}$ \\
\hline GrossReturn & $\begin{array}{l}-0.373 \\
(5.44)\end{array}$ & $\begin{array}{l}0.158 \\
(5.63)\end{array}$ & $\begin{array}{l}-0.137 \\
(5.68)\end{array}$ & \\
\hline TripleA & & $\begin{array}{l}3.158 \\
(3.21)\end{array}$ & $\begin{array}{l}3.104 \\
(3.15)\end{array}$ & $\begin{array}{l}4.442 \\
(3.22)\end{array}$ \\
\hline BankSponsor & & $\begin{array}{l}0.085 \\
(2.45)\end{array}$ & $\begin{array}{l}0.137 \\
(2.47)\end{array}$ & $\begin{array}{l}0.361 \\
(2.47)\end{array}$ \\
\hline ExpenseRatio & & $\begin{array}{l}0.237 \\
(3.25)\end{array}$ & $\begin{array}{l}0.545 \\
(3.36)\end{array}$ & $\begin{array}{l}1.642 \\
(3.97)\end{array}$ \\
\hline AssetSizeComplex & & $\begin{array}{l}-0.013 \\
(0.02)\end{array}$ & $\begin{array}{l}-0.009 \\
(0.02)\end{array}$ & $\begin{array}{l}-0.003 \\
(0.02)\end{array}$ \\
\hline DummyLehman & & & $\begin{array}{l}1.899 \\
(2.60)\end{array}$ & $\begin{array}{l}1.305 \\
(2.90)\end{array}$ \\
\hline DummyNonRepo & & & $\begin{array}{l}-2.512 \\
(2.75)\end{array}$ & $\begin{array}{l}-1.631 \\
(2.76)\end{array}$ \\
\hline MaturingIn7Days & & & & $\begin{array}{l}-1.080 \\
(10.98)\end{array}$ \\
\hline UsTreasury & & & & $\begin{array}{l}0.009 \\
(0.20)\end{array}$ \\
\hline AgencySecurity & & & & $\begin{array}{l}0.118 \\
(0.09)\end{array}$ \\
\hline Repo & & & & $\begin{array}{l}-0.037 \\
(0.08)\end{array}$ \\
\hline TimeDeposit & & & & $\begin{array}{l}-0.165 \\
(0.24)\end{array}$ \\
\hline DomesticBank & & & & $\begin{array}{l}-0.032 \\
(0.08)\end{array}$ \\
\hline ForeignBank & & & & $\begin{array}{l}0.045 \\
(0.07)\end{array}$ \\
\hline FloatingRate & & & & $\begin{array}{l}0.109 \\
(0.07)\end{array}$ \\
\hline $\mathrm{ABCP}$ & & & & $\begin{array}{l}0.008 \\
(0.09)\end{array}$ \\
\hline Constant & $\begin{array}{l}11.934 \\
(14.85)\end{array}$ & $\begin{array}{l}9.414 \\
(14.67)\end{array}$ & $\begin{array}{l}9.988 \\
(14.76)\end{array}$ & $\begin{array}{l}5.738 \\
(5.82)\end{array}$ \\
\hline R-square & 0.090 & 0.116 & 0.130 & 0.232 \\
\hline $\mathrm{P}$ & 0.028 & 0.145 & 0.189 & 0.227 \\
\hline $\mathrm{N}$ & 75 & 75 & 75 & 75 \\
\hline
\end{tabular}

$*^{* *}$, and ${ }^{* * *}$ indicate statistical significance at $10 \%, 5 \%$, and $1 \%$ respectively. Standard errors are in parentheses. 
Table 3: Effects of peer fund stability on own fund flows

This table presents the effect of peer funds' stability due to their enrollment in the Temporary Guarantee Program. We specify the following regression equation:

$$
\begin{aligned}
\text { Flow }_{f, c, t+1}= & \alpha+\gamma_{0} t+\sum_{\tau=0}^{2} \gamma_{1, \tau} \text { Enroll }_{c, t} \times S_{(-c), t-\tau}+\gamma_{2} \text { Enroll }_{c, t}+\sum_{\tau=0}^{2} \gamma_{3, \tau} S_{(-c), t-\tau} \\
& +\gamma_{4} \text { Flow }_{f, c, t}+\gamma_{5} \overline{F l o w}_{c(-f), t}+\gamma_{6} Y_{c}+\mu_{c, t}+u_{t}+\epsilon_{f, c, t+1},
\end{aligned}
$$

where $f$ is fund, $c$ is fund-complex, and $t$ is time. The dependent variable is fund flows of fund $f$ in fund complex $c$ in the next period $t+1$.

Enroll $_{c, t}$ is an indicator variable that is equal to 1 if a fund complex $c$ was enrolled in the temporary guarantee as of $t$; $S_{(-c), t}$ is an external stability measure from peer funds' enrollment in the Temporary Guarantee Program defined as $S_{(-c), t} \equiv$ $\sum_{k \neq c} 1\left\{t=\bar{t}_{k}\right\} \times W_{k}$ where $W_{k}$ is the risk proxy of a fund complex $k$. $S_{(-c), t-\tau}$ is lagged value of peer funds' stability measures with time lag $\tau$. The first-differenced model is estimated with time fixed effects to control for unobservable fund-level, complex-level, and time-specific shocks. The time period covered is September 29-December 19, 2008 which is the first term of the guarantee program. Generalized least squares (GLS) is used to estimate the model for efficiency gains in the face of a time-varying variance of the error term $\epsilon_{f, c, t}$ (Wooldridge (2002)).

Each column represents a different proxy for risk $\left(W_{k}\right)-(1)$ : the equal weigting; (2): outflow right after Lehman's bankruptcy (September 15-19, 2008); (3): number of portfolios that had non-secured securities issued by Lehman Brothers; (4): log asset size of portfolios that had non-secured securities issued by Lehman Brothers; (5): number of portfolios that had non-agency repo transactions; (6): log asset size of portfolios that had non-agency repo transactions; (7): correlation between funds' gross yields for the past 12 months.

The main coefficients of interest are $\left\{\gamma_{1, \tau}\right\}_{\tau=0}^{\tau=2}$ which measure the asymmetric externality of peers' stability to already-enrolled and non-enrolled funds. Negative $\gamma_{1, \tau}$ implies that non-enrolled funds benefited more from peers' stability thanks to their prior enrollment in the Temporary Guarantee Program.

\begin{tabular}{llllllll}
\hline & $\begin{array}{c}\text { Proxy } \\
(1)\end{array}$ & \multicolumn{1}{c}{$\begin{array}{c}\text { Proxy } \\
(2)\end{array}$} & $\begin{array}{c}\text { Proxy } \\
(3)\end{array}$ & $\begin{array}{c}\text { Proxy } \\
(4)\end{array}$ & $\begin{array}{c}\text { Proxy } \\
(5)\end{array}$ & $\begin{array}{c}\text { Proxy } \\
(6)\end{array}$ & $\begin{array}{c}\text { Proxy } \\
(7)\end{array}$ \\
\hline Enroll $\times$ Peer Stability $(-2)$ & $-0.041^{* *}$ & $-0.005^{* *}$ & $-0.043^{* * *}$ & $-0.034^{* *}$ & $-0.045^{* * *}$ & $-0.036^{* * *}$ & $-0.036^{* *}$ \\
& $(0.02)$ & $(0.00)$ & $(0.02)$ & $(0.01)$ & $(0.01)$ & $(0.01)$ & $(0.01)$ \\
Enroll $\times$ Peer Stability $(-1)$ & -0.012 & $-0.003^{* *}$ & -0.009 & -0.016 & -0.004 & -0.006 & -0.015 \\
& $(0.02)$ & $(0.00)$ & $(0.02)$ & $(0.01)$ & $(0.01)$ & $(0.01)$ & $(0.01)$ \\
Enroll $\times$ Peer Stability $(0)$ & -0.015 & $-0.004^{* *}$ & -0.019 & -0.011 & $-0.025^{*}$ & -0.020 & -0.010 \\
& $(0.02)$ & $(0.00)$ & $(0.02)$ & $(0.01)$ & $(0.02)$ & $(0.01)$ & $(0.01)$ \\
Enroll & $0.568^{* *}$ & $0.703^{* * *}$ & $0.638^{* * *}$ & $0.609^{* * *}$ & $0.695^{* * *}$ & $0.676^{* * *}$ & $0.560^{* * *}$ \\
& $(0.24)$ & $(0.19)$ & $(0.19)$ & $(0.18)$ & $(0.20)$ & $(0.20)$ & $(0.18)$ \\
Lagged Flow & $-0.516^{* * *}$ & $-0.516^{* * *}$ & $-0.516^{* * *}$ & $-0.516^{* * *}$ & $-0.516^{* * *}$ & $-0.516^{* * *}$ & $-0.516^{* * *}$ \\
& $(0.01)$ & $(0.01)$ & $(0.01)$ & $(0.01)$ & $(0.01)$ & $(0.01)$ & $(0.01)$ \\
Lagged Peer Fund Flow & $0.006^{*}$ & $0.006^{*}$ & $0.006^{*}$ & $0.006^{*}$ & $0.006^{*}$ & $0.006^{*}$ & $0.006^{*}$ \\
& $(0.00)$ & $(0.00)$ & $(0.00)$ & $(0.00)$ & $(0.00)$ & $(0.00)$ & $(0.00)$ \\
Time FE & Yes & Yes & Yes & Yes & Yes & Yes & Yes \\
Joint Test $\left(\left\{\beta_{1 \tau}\right\}_{\tau=0}^{\tau=2}\right)$ & 0.061 & 0.040 & 0.035 & 0.053 & 0.019 & 0.039 & 0.075 \\
\hline $\mathrm{N}$ & 9111 & 9111 & 9111 & 9111 & 9111 & 9111 & 9111 \\
\hline
\end{tabular}

${ }^{*}, * *$, and $* * *$ indicate statistical significance at $10 \%, 5 \%$, and $1 \%$ respectively. Standard errors are in parentheses. 
Table 4: Analysis of investor behavior before/after the guarantee program: Retail vs. institutional

This table shows that retail and institutional investors behaved differently before and after the introduction of the Temporary Guarantee Program. The following model is estimated:

$$
\text { Flow }_{s, f, c, t}=\beta_{0}+\sum_{\tau=2}^{5} \beta_{1, \tau}\left(I_{s, f, c} \times P_{t(\tau)}\right)+\beta_{2} I_{s, f, c}+\sum_{\tau=2}^{5} \beta_{3, \tau} P_{t(\tau)}+\beta_{4} X_{f, c, t}+\beta_{5} Y_{c}+u_{s, f, c, t},
$$

where Flow $_{s, f, c, t}$ is the daily flows of share class $s$, fund $f$, fund complex $c$ at time $t ; I_{s, c, f}$ is an indicator for an investor base (0: institutional, 1: retail); $P_{t(\tau)}$ is an indicator for a phase which is 1 if $t$ belongs to time frame $\tau$ and zero otherwise; phase $\tau$ is defined to be 1: September 15-19, 2008; 2: September 20-29, 2008; 3: September 30-December 18, 2008; 4: December 19, 2008-April 30, 2009; and 5: May 1-December 18, 2009. In other words, time frame 1 represents the period of the Lehman crisis, 2 represents the introduction period of the Temporary Guarantee Program, 3 represents the period of the first term of the Guarantee Program, 4 represents the second term, and 5 represents the the third term. $X_{f, c, t}$ includes the fund portfolio yield, $\nu_{f}$ is a fund level common shock, and $\mu_{c}$ is a fund complex level common shock.

The result shows that retail investors invested less in prime money market funds compared with institutional investors even after the Temporary Guarantee Program became effective. However, in government money market funds, retail investors behaved in a similar way to institutional investors.

\begin{tabular}{|c|c|c|c|c|c|c|}
\hline & $\begin{array}{c}\text { Prime } \\
(1)\end{array}$ & $\begin{array}{c}\text { Prime } \\
(2)\end{array}$ & $\begin{array}{c}\text { Prime } \\
(3)\end{array}$ & $\begin{array}{c}\text { Govt } \\
(4)\end{array}$ & $\begin{array}{c}\text { Govt } \\
(5)\end{array}$ & $\begin{array}{c}\text { Govt } \\
(6)\end{array}$ \\
\hline \multirow[t]{2}{*}{ Retail $\times$ Phase 2} & -0.138 & -0.138 & -0.138 & -0.494 & -0.496 & -0.495 \\
\hline & $(0.11)$ & $(0.11)$ & $(0.11)$ & $(0.92)$ & $(0.92)$ & $(0.95)$ \\
\hline \multirow[t]{2}{*}{ Retail $\times$ Phase 3} & $-0.034^{* * *}$ & $-0.034^{* * *}$ & $-0.034^{* * *}$ & -0.949 & -0.943 & -0.950 \\
\hline & $(0.01)$ & $(0.01)$ & $(0.01)$ & $(0.71)$ & $(0.71)$ & $(0.78)$ \\
\hline \multirow[t]{2}{*}{ Retail $\times$ Phase 4} & $-0.038^{* * *}$ & $-0.038^{* * *}$ & $-0.038^{* * *}$ & -1.042 & -1.030 & -1.041 \\
\hline & $(0.01)$ & $(0.01)$ & $(0.01)$ & $(0.70)$ & $(0.70)$ & $(0.78)$ \\
\hline \multirow[t]{2}{*}{ Retail $\times$ Phase 5} & $-0.039 * * *$ & $-0.039^{* * *}$ & $-0.040^{* * *}$ & -1.028 & -1.022 & -1.029 \\
\hline & $(0.01)$ & $(0.01)$ & $(0.01)$ & $(0.71)$ & $(0.70)$ & $(0.78)$ \\
\hline \multirow[t]{2}{*}{ Phase2 } & 0.135 & 0.135 & 0.135 & -0.001 & -0.005 & -0.004 \\
\hline & $(0.11)$ & $(0.11)$ & $(0.11)$ & $(0.00)$ & $(0.02)$ & $(0.02)$ \\
\hline \multirow[t]{2}{*}{ Phase3 } & $0.033^{* * *}$ & $0.033^{* * *}$ & $0.033^{* * *}$ & $-0.019 * * *$ & -0.032 & -0.029 \\
\hline & $(0.01)$ & $(0.00)$ & $(0.01)$ & $(0.00)$ & $(0.07)$ & $(0.06)$ \\
\hline \multirow[t]{2}{*}{ Phase4 } & $0.036^{* * *}$ & $0.035 * * *$ & $0.037^{* * *}$ & $-0.018^{* * *}$ & -0.048 & -0.039 \\
\hline & $(0.00)$ & $(0.00)$ & $(0.01)$ & $(0.01)$ & $(0.12)$ & $(0.12)$ \\
\hline \multirow[t]{2}{*}{ Phase5 } & $0.035^{* * *}$ & $0.034^{* * *}$ & $0.038^{* * *}$ & -0.013 & -0.054 & -0.041 \\
\hline & $(0.01)$ & $(0.01)$ & $(0.01)$ & $(0.01)$ & $(0.15)$ & $(0.14)$ \\
\hline \multirow[t]{2}{*}{ Retail } & $0.035 * * *$ & $0.034^{* * *}$ & $0.035^{* * *}$ & 1.025 & 1.037 & 1.064 \\
\hline & $(0.01)$ & $(0.01)$ & $(0.01)$ & $(0.70)$ & $(0.70)$ & $(0.77)$ \\
\hline \multirow[t]{2}{*}{ Yield } & & -0.001 & 0.001 & & -0.019 & -0.013 \\
\hline & & $(0.00)$ & $(0.00)$ & & $(0.08)$ & $(0.08)$ \\
\hline Fund Complex FE & No & No & Yes & No & No & Yes \\
\hline Portfolio FE & Yes & No & No & Yes & No & No \\
\hline $\mathrm{N}$ & 171680 & 171680 & 171680 & 166286 & 165167 & 165167 \\
\hline
\end{tabular}

$*, * *$, and $* * *$ indicate statistical significance at $10 \%, 5 \%$, and $1 \%$ respectively. Standard errors are in parentheses. 
Figure 1: Distribution of fund complexes' announcement timing of enrollment in the TGP

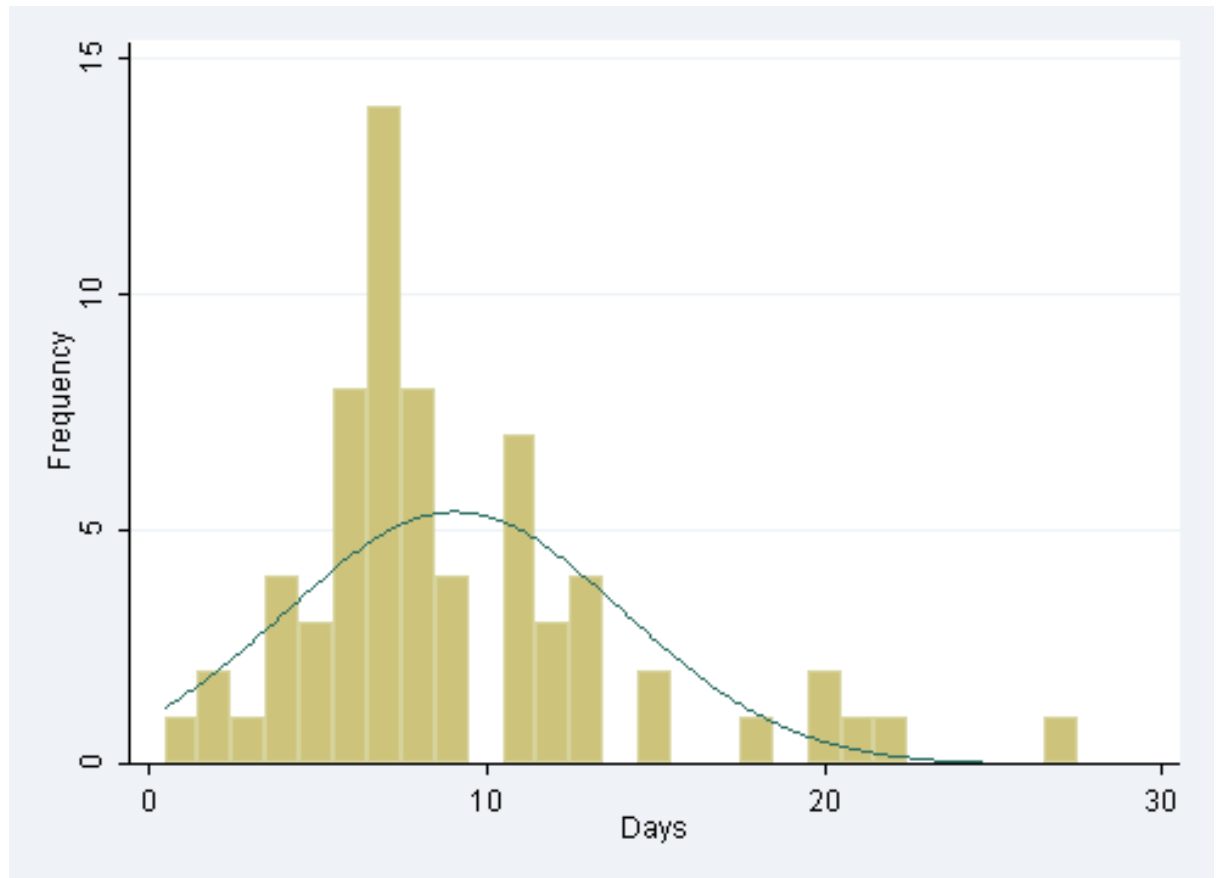

This graph plots the distribution of announcement dates of enrollment in the Temporary Guarantee Program by fund complexes. The unit is the number of trading days from September 29, 2008 until the announcement date. Source: SEC disclosure documents (Form 497) and author's calculation. 
Figure 2: Asymmetric spillover effects of peer funds' TGP enrollment announcement
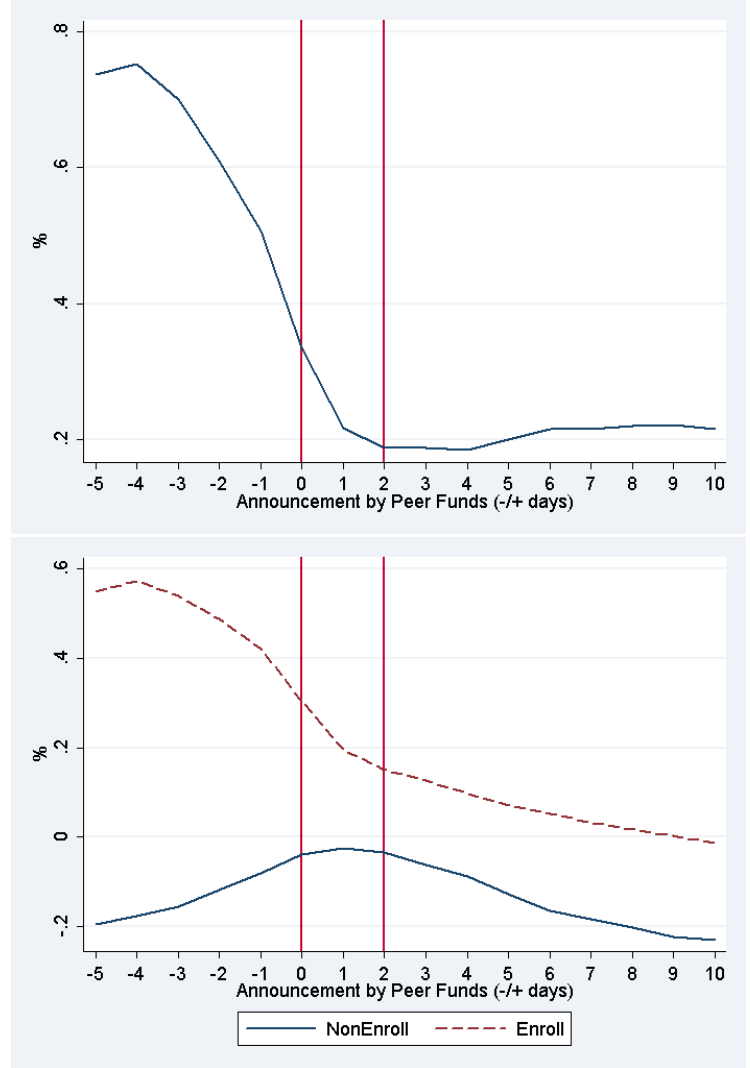

This graph shows the pattern of average fund flow differences between already-enrolled and non-enrolled funds around peer funds' enrollment announcements in the guarantee program. The first vertical line indicates the date of peer funds' announcement. The flow pattern implies that the spillover effect of peer funds' stability was greater for non-enrolled funds than already-enrolled funds. If the spillover effect of peer funds stability were greater for non-enrolled funds, then the flow difference between enrolled and non-enrolled funds would have to be narrowed after peer funds' enrollment announcement, which is what this graph shows. A two-day lag of externality is consistent with the regression analysis result. For the already-enrolled funds, flow data since the two days after their own announcement was included to control for the impact of their own announcement on the fund flows. Kernel-weighted local polynomial smoothing was used to plot the flow patterns. Source: Author's calculation. 
Figure 3: Money market funds asset under management by investment and investor type
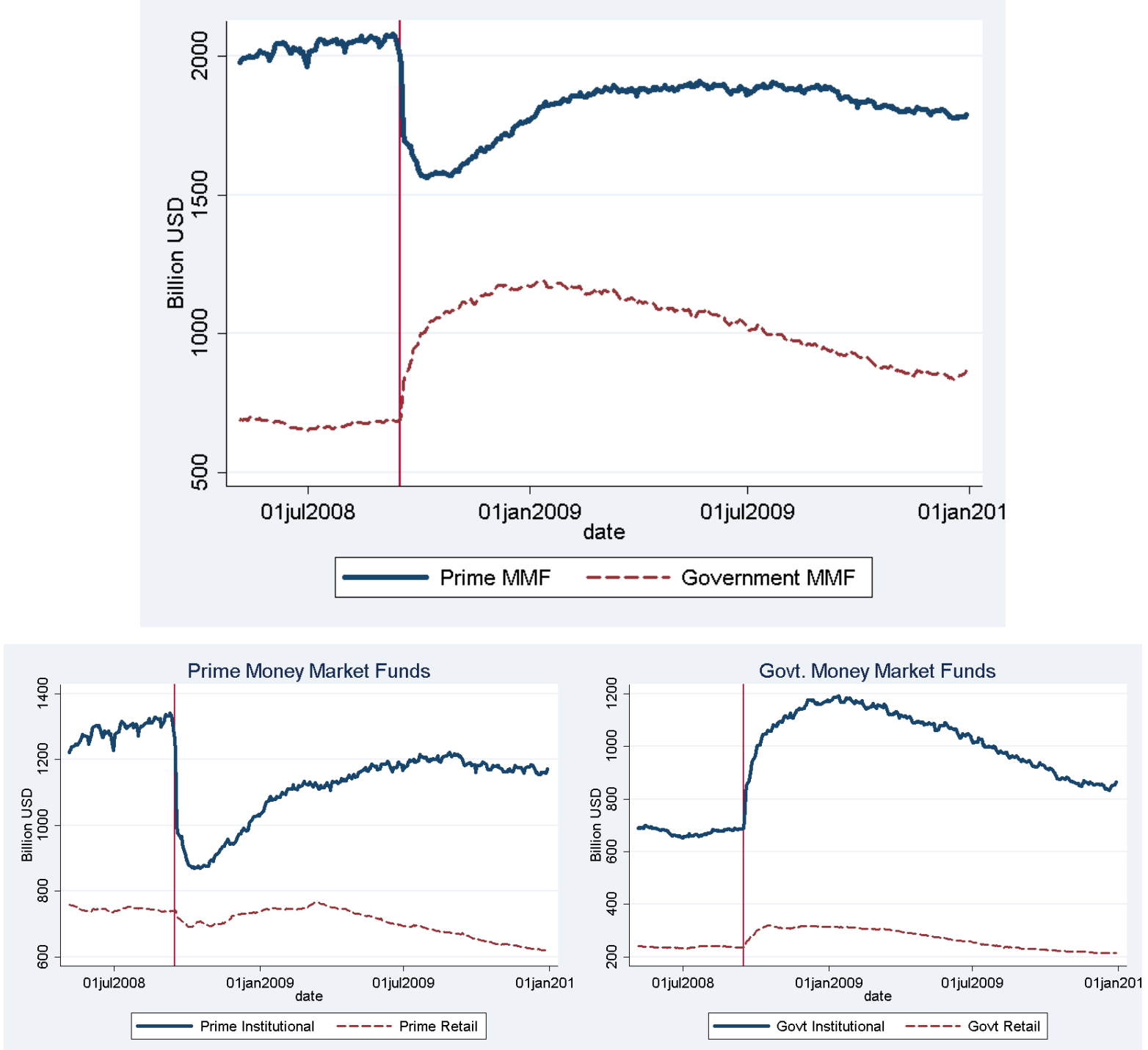

These graphs show the trend of assets under management of U.S. money market funds by categories of investment and investors. The vertical line indicates the date of Lehman's collapse (September 15, 2008). The upper panel shows that there was a flight to quality episode: Investors withdrew from prime money market funds immediately following the Lehman shock and invested in government money market funds. The lower left panel shows a stark difference between retail and institutional investors in prime money market funds. Even after the Temporary Guarantee Program was effective, retail investors did not return and continue to withdraw their investments, while institutional investors returned to their funds. The lower right panel shows that institutional and retail investors of government money market funds behaved in a similar way while the Temporary Guarantee Program was effective. Source: iMoneyNet and author's calculation. 
Figure 4: Amounts loaned under the AMLF program

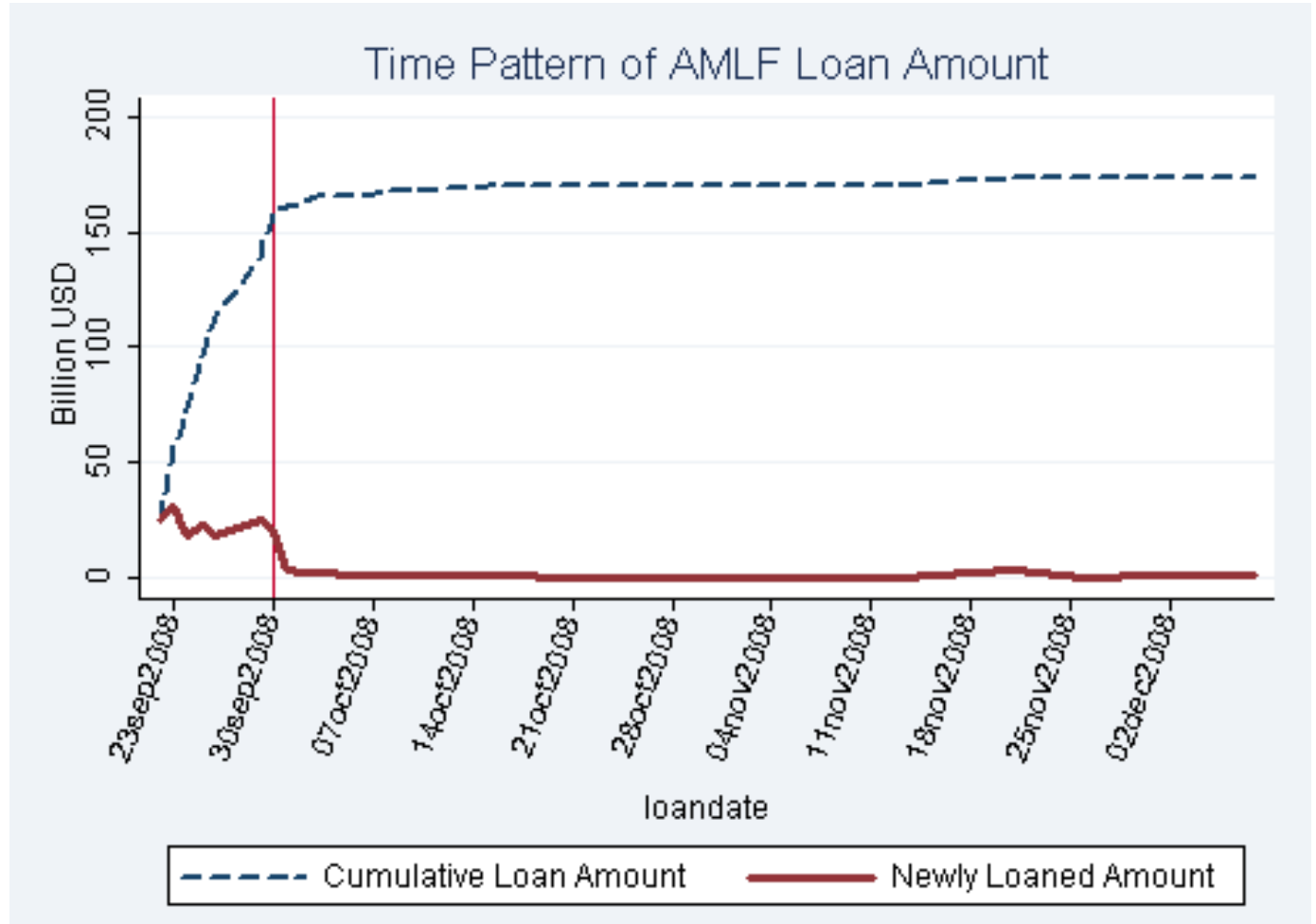

This graph shows the pattern of amounts loaned under the the Federal Reserve Board's Asset-backed Commercial Paper Money Market Mutual Fund Liquidity Facility (AMLF), which was launched on the same day as the Treasury Department's Temporary Guarantee Program. The vertical line indicates the date of the first enrollment announcement in the guarantee program. This graphs implies that the AMLF program was not used extensively after fund complexes began to announce their enrollment in the Temporary Guarantee Program. Source: Federal Reserve Board and author's calculation. 
Figure 5: Fund flow patterns in money market funds: Prime vs. Government funds
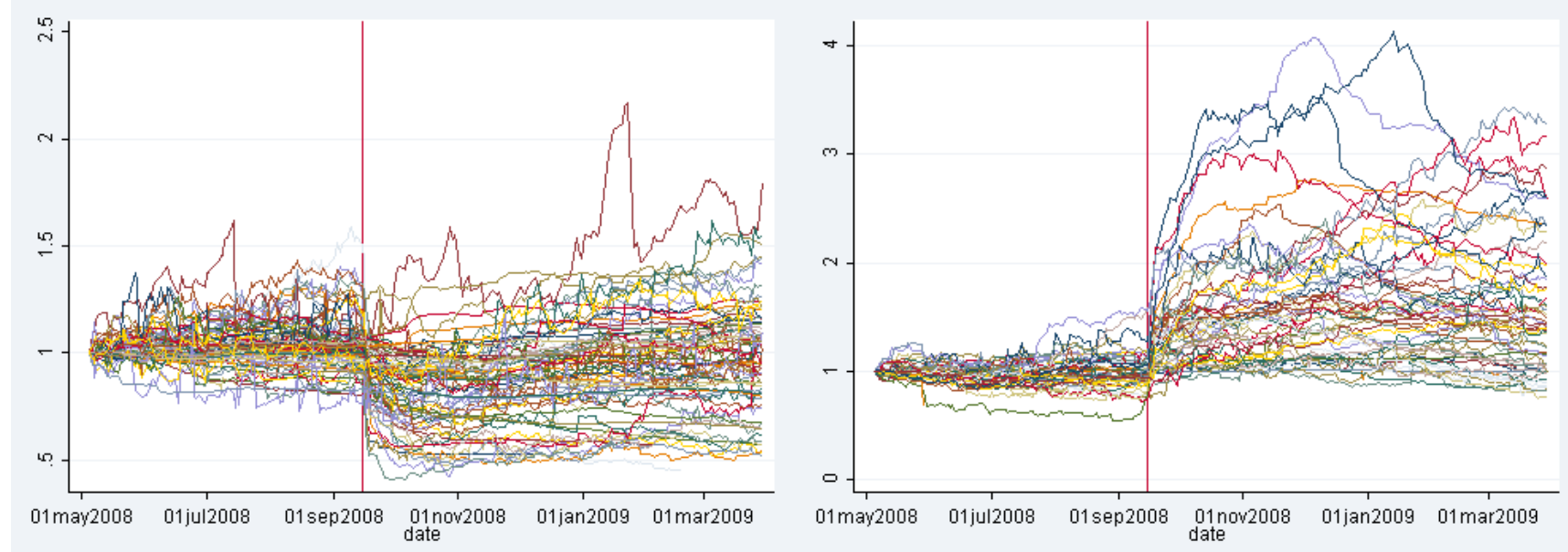

This graphs shows there were substantial differences between funds in terms of fund flows after the Lehman shock. The left panel shows the individual funds' daily flows in prime money market funds, and the right shows the daily flows in government money market funds. The vertical line indicates the date of Lehman's collapse (September 15, 2008). Each fund's asset size was normalized at one as of May 1, 2008. Source: iMoneyNet and author's calculation. 


\section{Web Appendix}

\section{A Hypothesis development of contagious runs}

This section provides models that apply the theoretical framework of Goldstein (2005) and Goldstein and Pauzner (2005) to two money market fund settings. The goal of the first model is to capture in the simplest way the effect of the Temporary Guarantee Program (TGP) on strategic complementarity between money market funds. In particular, we make a simple assumption about the interlinkage of money market funds via common collateral of repurchase agreement and focus on the predicted effect of the Temporary Guarantee Program in reducing the probability of a panic-driven run. The case of shared investment is omitted here because it will be a trivial extension of the presented model.

\section{A.1 Setting}

There are two periods, $t=1,2$. Two groups of continuum investors $I_{1}$ and $I_{2}$ invest one unit of resource in two funds, respectively. The funds allow investors to withdraw their investments early at $t=1$, or hold until $t=2$. With resources received from investors, funds invest in long-term investments. These long-term investments are assumed to be extremely illiquid, so the liquidation value at $t=1$ is assumed to be 040 Thus, the investments should remain active (rolled over) until $t=2$ to finance these projects effectively.

To hedge against borrowers' default risk at $t=2$ and honor possible redemption requests at $t=1$, funds request borrowers to pledge collateral. The function of money market funds can be considered as a delegated agent of writing collateralized lending. Investment should be rolled over until $t=2$ when it yields $R_{i}$ with probability $1-\theta_{i}$ or yields 0 with probability $\theta_{i}$ in which case the collateral should be sold at its market price. To highlight our results, we assume the two projects have mutually independent default risk $\left\{\theta_{1}, \theta_{2}\right\}$. Let $r_{1}$ and $r_{2}$ denote the short-term rate for each money market fund. Actually, this should be equal to the risk-free rate since the posted collateral makes the investment risk-free. Note that we do not consider any investors' learning mechanism here. Since the default risks are independent across funds, there is nothing to learn from investors' behavior in other funds.

We assume borrowers and money market funds cannot raise additional capital. Thus, funds have to sell collateral to honor early redemption requests by investors at $t=1$ (Morris and Shin (2004)). We also assume each fund receive the same asset class as collateral. If a certain asset class is considered to be liquid and safe enough to serve as collateral, it will be widely used in secured lending contracts in the capital

\footnotetext{
${ }^{40}$ This assumption can be relaxed to have lower recovery rate than the promised payment in the short-term.
} 
market. Moreover, its liquidity characteristic will be preserved only because many lenders are willing to receive this asset class as collateral. Thus the very purpose of collateral implies that the asset class serving as collateral is widely held by many funds and its price can be affected by selling/buying volume in the market 41

The collateral's market price $p_{1}$ at $t=1$ is assumed to be influenced by selling volume of this asset class. Another way to interpret this is that collateral price is sensitive to supply/demand because it is made of tradable illiquid long-term assets (Kacperczyk and Schnabl $(2010))$. More specifically, $p_{1}\left(n_{1}, n_{2}\right)$ is a decreasing function in the short-term withdrawal volume ( $n_{1}$ and $n_{2}$ for each institution) ${ }^{42}$ At $t=2$, the collateral price converges to $f(\mu)$ which is assumed to be increasing in its intrinsic value $(\mu)$.

At $t=1$, investors receive a noisy signal about the default probability of the project in their funds. An investor (labeled as $j$ ) at fund $i$ receives a signal $x_{i}^{j}$ that is the sum of the true default risk $\theta_{i}$ and a noise term $\tilde{\epsilon}_{i}$ :

$$
x_{i}^{j}=\theta_{i}+\tilde{\epsilon}_{i}^{j}
$$

For simplicity, we assume $\left\{\theta_{1}, \theta_{2}\right\}$ are independently drawn from the uniform distribution on $[0,1]$ and $\left\{\tilde{\epsilon}_{1}, \tilde{\epsilon}_{2}\right\}$ are independently drawn from the uniform distribution on $[-\epsilon, \epsilon]$. The signal can be interpreted as each agent's private information about the quality of projects held by funds. Since agents delegate to funds all investment decisions and the rights to sign contracts for collateralized lending, agents may have only indirect channels or technology to collect information about the true quality of projects.

Fund $i$ promises to pay fixed return $r_{i}$ to investors when they seek to withdraw at $t=1$. If an investor chooses to wait, he will receive a return at $t=2$ or the value of collateral in the case of the project's default. If the collateral's market value is lower than the promised return (that is, $p_{1}<r_{i}$ ), the fund must sell more shares of collateral at the market price in order to honor the promised payment to investors. This is because each investor will receive a promised payment $r_{i}$, even though the market-base NAV $\left(p_{1}\right)$ is lower than $r_{i}$. If the fund has run short, any late withdrawal request will not be honored. The payoff gain of running

\footnotetext{
${ }^{41}$ As noted by Gorton and Metrick $(2012)$ and Kacperczyk and Schnabl (2010), the real-world counterpart of this model would be that MMFs buy asset-backed commercial paper (ABCP) issued by special purpose vehicles (SPVs), which seek to use the capital to finance their mortgage products or related businesses. MMFs receive AAA-tranches of mortgage-backed securities (MBS) as collaterals.

${ }^{42}$ Compare Diamond and Rajan (2005), who indicated that the "common pool of liquidity" is abated by some bank failures, which will affect other banks' balance sheets. Cifuentes, Ferrucci and Shin (2005) presented that the sale of illiquid assets by failed banks can generate a negative externality to other banks via a market-to-market scheme.
} 
compared to waiting at $t=1$ is as follows:

$$
\begin{aligned}
& v_{i}\left(\theta_{i}, n_{i}\left(k, \theta_{i}\right) ; n_{-i}\right) \\
= & u\left(r_{i}\right) \\
& -\{\underbrace{\theta_{i} u\left(\min \left\{\left(\frac{1-\frac{r_{i}}{p_{1}\left(n_{i} n_{-i}\right)} n_{i}}{1-n_{i}}\right) f(\mu), R_{i}\right\}\right)}_{\text {in case of default }}+\underbrace{\left(1-\theta_{i}\right) u\left(R_{i}\right)}_{\text {in case of success }}\},
\end{aligned}
$$

where $k$ is other investors' cutoff point for the switching strategy. We are considering the non-recourse debt contract, so the lender can collect repayment only up to the collateral value should in the borrower default. If the collateral price $p_{1}$ at $t=1$ is sufficiently higher than the promised payment $r_{i}$ (that is, $p_{1} \geq r_{i}$ ), the fund does not have to sell more shares of collateral to meet redemption requests at $t=1$. Therefore, the sequential service constraint is not binding. ${ }^{43}$ Nevertheless, as the withdrawal request mounts $\left(n_{i} \uparrow\right)$, there will be more downward pressure on $p_{1}$ and funds may need to sell the collateral at a distressed price.44 This makes sense especially when the AAA-rated collateral asset was believed to be very safe, but turned out to be low quality, which occurred in the recent financial crisis 45 Note that we only consider the case when fund $i$ is solvent (that is, $\left.p_{1}\left(n_{i} ; n_{-i}\right)>r_{i} n_{i}\right)$. The insolvent case is omitted because it does not change our result.

\section{A.2 Investors' optimal behaviors and the impact of the Temporary Guarantee Program}

We allow two possible extreme ranges for the project's default risk at $t=2$. As assumed in many applications of the theory of global games, we impose conditions on the range of default risk $\theta_{i}$ for each fund as follows:

Lower dominance region of the project's default: $\exists \underline{\theta}_{i}$ such that $\forall \theta_{i}<\underline{\theta}_{i}, v_{i}\left(\theta_{i}, n_{i}\left(k, \theta_{i}\right) ; n_{-i}\right)<0$ for all $n_{i} \in[0,1]$ and $n_{-i}$. In other words, as long as the project quality is very safe, the collateral value or others' behavior does not matter. Waiting is a dominant strategy at $t=1$ regardless of other investors' choices at $t=1$.

Upper dominance region of the project's default: $\exists \bar{\theta}_{i}$ such that $\forall \theta_{i}>\bar{\theta}_{i}, v_{i}\left(\theta_{i}, n_{i}\left(k, \theta_{i}\right) ; n_{-i}\right)>0$ for all $n_{i} \in[0,1]$ and $n_{-i}$. This condition indicates that if the default probability is too high, the collateral

\footnotetext{
${ }^{43}$ In other words, late comers can always redeem shares regardless of their peer investors because the fund does not have to sell more shares than the withdrawal request.

${ }^{44} \mathrm{We}$ assume $p_{1}$ is depressed enough for large $n_{i}$ so that the single crossing condition of $v_{i}$ is satisfied (Morris and Shin (2000)). $\partial\left(1-\frac{r_{i}}{p_{1}\left(n_{i} ; n_{-i}\right)} n_{i}\right) / \partial n_{i}=\left[p_{1}\left(n_{i} ; n_{-i}\right)^{2}-p_{1}\left(n_{i} ; n_{-i}\right) r_{i}+r_{i} n_{i}\left(1-n_{i}\right) p_{1}^{\prime}\left(n_{i} ; n_{-i}\right)\right] /\left(1-n_{i}\right)^{2} p_{1}\left(n_{i} ; n_{i}\right)^{2}$. As long as $p_{1}$ is depressed enough with large $n_{i}$, we can even show monotonicity condition, but the single crossing condition will be enough for our purpose.

${ }^{45}$ Again, haircut was not enough to cover the loss.
} 
value will be too low to fully recover the promised payment should the borrower default at $t=2$. Therefore, running is a dominant strategy regardless of other investors' choices at $t=1$.

As in the review article Morris and Shin (2000), we can show that, for all $n_{-i}$, there exists a unique threshold $\theta_{i}^{*}\left(n_{-i}\right)$ above which investors in fund $i$ run on the fund 46 This cutoff point $\theta_{i}^{*}\left(n_{-i}\right)$ is the best response function of fund $i$ 's investors in response to the fund $-i$ 's withdrawal volume.

The direction of $\theta_{i}^{*}\left(n_{-i}\right)$ with respect to a change in $n_{-i}$ provides an important implication for the contagious runs across money market funds. We define the expected payoff gain of running in the following way:

$$
\mathcal{L}\left(\theta_{i} ; n_{-i}\right) \equiv \int_{n_{i}=0}^{1} v_{i}\left(\theta_{i}, n_{i} ; n_{-i}\right) d n_{i}
$$

Because $p_{1}\left(n_{i} ; n_{-i}\right)$ is decreasing in $n_{-i}, v_{i}\left(\theta_{i}, n_{i} ; n_{-i}\right)$ is increasing in $n_{-i}$. Thus, $\mathcal{L}\left(\theta_{i} ; n_{-i}\right)$ is increasing in $n_{-i}$ for all $\theta_{i}$. Since $\mathcal{L}\left(\theta_{i} ; n_{-i}\right)$ is increasing in $\theta_{i}$, the cutoff signal $\theta_{i}^{*}\left(n_{-i}\right)$ that makes $\mathcal{L}\left(\theta_{i} ; n_{-i}\right)=0$ should be decreasing in $n_{-i}$. We highlight this result as in the following proposition:

Proposition. $\theta_{i}^{*}\left(n_{-i}\right)$ is decreasing in $n_{-i}$.

This result implies that investors' decisions in fund $i$ affect investors' decisions in another fund even though the projects' default risks $\left\{\theta_{1}, \theta_{2}\right\}$ are independently distributed. When Fund 1's investors observe that Fund 2 is run by its investors, they are more likely to run on Fund 1. The intuition behind this result lies in the market value of collateral held by funds. When Fund 1 is facing a mass withdrawal request, it must sell the collateral to honor those requests which, in turn, generates downward pressure on the market value of the collateral asset. Investors' tolerance for bearing default risk decreases due to negative externality from other funds via the collateral channel. Fund 2 faces a negative externality from Fund 1 investors' behavior, in the sense that the collateral's market value held by Fund 2 is likely to decrease because their collaterals were in the same asset class. Note that this contagion is not triggered by information updating about the collateral values since we assume no uncertainty on the value of collateral $(f(\mu))$ at this time. In this setting, the two groups of investors in different funds are exchanging externalities through the collateral channel.

Under the contagion effect, the Treasury Department's Temporary Guarantee Program generates positive externality across funds. Assume that Fund 1 announces its enrollment in the Temporary Guarantee Program earlier than its peer Fund 2 for some reason. This eliminates the panic problem among investors in Fund 1 because the strategic complementarity among investors is believed to be absorbed by the Treasury Department. In the above model setting, the enrollment will make the cutoff point $\theta_{1}^{*}\left(n_{2}\right)$ equal to 1

\footnotetext{
${ }^{46}$ The proof is omitted here because of space limit, but the author will provide it upon request.
} 
regardless of $n_{2}$, and there will not be a run on Fund 1. Interestingly, even though Fund 2 did not yet enroll in the Temporary Guarantee Program, the likelihood of run on Fund 2 also decreases because the contagion risk from Fund 1 is eliminated with the guarantee program and the threshold of run $\theta_{2}^{*}\left(n_{1}=0\right)$ in Fund 2 increases towards 1 according to the above Proposition. In other words, the guarantee program can work as a device to cut the chain of contagion.

An empirical test of the impact of the announcement of enrollment in the guarantee program enables us to uncover the presence of the strategic complementarity across funds. Showing the positive externality effect of enrolled funds on other non-enrolled funds will provide evidence for contagion risk of runs. In other words, we are looking for the flipside of contagious runs - the spread of stability — across money market funds. This is the rationale for Hypothesis 1. Because the announcement was usually made in a fund complex level, testing this hypothesis will provide evidence for contagious runs across funds. 


\section{B Data Sources}

\section{B.1 iMoneyNet}

1. iMoneyNet reports information in share classes. We grouped several share classes into one portfolioID based on their portfolio asset size. When several share classes had the same portfolio size at the same date, we assigned the same portfolioID to them.

2. Each fund has a Ticker symbol that can be used to extract portfolio information from SEC disclosure system (EDGAR).

\section{B.2 SEC EDGAR system}

1. We used a web-crawler to extract all relevant forms (Form 497, Form N-Q, Form N-CSR).

2. We manually extracted portfolio information (unsecured debt issued by Lehman, repo transactions collateralized by U.S. government and non-governmental agency securities) from the schedule of investment section in the quarterly disclosure document as of the latest quarter from September 15, 2008.

3. We manually extracted enrollment date of funds in the Temporary Guarantee Program from the Form 497 (Definitive Materials). 


\section{Robustness check and additional analyses}

\section{C.1 Robustness check}

Table 5: Robustness Check 1: Effect of peer fund stability across fund complexes excluding retail-oriented fund complexes

This table presents the effect of peer funds' stability thanks to enrollment in the Temporary Guarantee Program excluding retail-oriented fund complexes. We conduct the analysis with only institutional-oriented fund complexes during September 28-December 19, 2008. We define institutional-oriented fund complexes as those in which institutional-investors' asset size exceeded more than $50 \%$ of the total assets on average over six months (March 15-September 15, 2008).

Each column represents a different proxy of risk $\left(W_{k}\right)$ - (1): the equal weighting; (2): outflow right after Lehman's bankruptcy (September 15-19, 2008); (3): number of portfolios that had non-secured securities issued by Lehman Brothers; (4): log asset size of portfolios that had non-secured securities issued by Lehman Brothers; (5): number of portfolios that had non-agency repo transactions; (6): log asset size of portfolios that had non-agency repo transactions; (7): correlation between funds' gross yield for the past 12 months.

\begin{tabular}{llllllll}
\hline & $\begin{array}{c}\text { Proxy } \\
(1)\end{array}$ & \multicolumn{1}{c}{$\begin{array}{c}\text { Proxy } \\
(2)\end{array}$} & $\begin{array}{c}\text { Proxy } \\
(3)\end{array}$ & $\begin{array}{c}\text { Proxy } \\
(4)\end{array}$ & $\begin{array}{c}\text { Proxy } \\
(5)\end{array}$ & $\begin{array}{c}\text { Proxy } \\
(6)\end{array}$ & $\begin{array}{c}\text { Proxy } \\
(7)\end{array}$ \\
\hline Enroll $\times$ Peer Stability $_{(-2)}$ & $-0.067^{* *}$ & $-0.007^{* *}$ & $-0.068^{* *}$ & $-0.054^{* *}$ & $-0.074^{* * *}$ & $-0.054^{* *}$ & $-0.067^{* *}$ \\
& $(0.03)$ & $(0.00)$ & $(0.03)$ & $(0.02)$ & $(0.03)$ & $(0.02)$ & $(0.03)$ \\
Enroll $\times$ Peer Stability $(-1)$ & -0.039 & $-0.007^{* * *}$ & $-0.042^{*}$ & $-0.047^{* *}$ & -0.027 & -0.033 & $-0.041^{*}$ \\
& $(0.03)$ & $(0.00)$ & $(0.03)$ & $(0.02)$ & $(0.02)$ & $(0.02)$ & $(0.02)$ \\
Enroll $\times$ Peer Stability $(0)$ & -0.038 & $-0.008^{* * *}$ & $-0.045^{*}$ & -0.028 & $-0.060^{* *}$ & $-0.048^{* *}$ & -0.027 \\
& $(0.03)$ & $(0.00)$ & $(0.03)$ & $(0.02)$ & $(0.03)$ & $(0.02)$ & $(0.02)$ \\
Enroll & $1.063^{* *}$ & $1.361^{* * *}$ & $1.284^{* * *}$ & $1.327^{* * *}$ & $1.218^{* * *}$ & $1.173^{* * *}$ & $1.139^{* * *}$ \\
& $(0.44)$ & $(0.36)$ & $(0.44)$ & $(0.36)$ & $(0.40)$ & $(0.38)$ & $(0.31)$ \\
Lagged Flow & $-0.510^{* * *}$ & $-0.511^{* * *}$ & $-0.510^{* * *}$ & $-0.510^{* * *}$ & $-0.510^{* * *}$ & $-0.509^{* * *}$ & $-0.510^{* * *}$ \\
& $(0.01)$ & $(0.01)$ & $(0.01)$ & $(0.01)$ & $(0.01)$ & $(0.01)$ & $(0.01)$ \\
Lagged Peer Fund Flow & $0.011^{* *}$ & $0.011^{* *}$ & $0.011^{* *}$ & $0.011^{* *}$ & $0.010^{* *}$ & $0.011^{* *}$ & $0.011^{* *}$ \\
Time FE & $(0.00)$ & $(0.01)$ & $(0.00)$ & $(0.00)$ & $(0.00)$ & $(0.00)$ & $(0.00)$ \\
Joint Test $\left(\left\{\beta_{1 \tau}\right\}_{\tau=0}^{\tau=2}\right)$ & Yes & Yes & Yes & Yes & Yes & Yes & Yes \\
\hline $\mathrm{N}$ & 0.031 & 0.006 & 0.014 & 0.015 & 0.007 & 0.016 & 0.030 \\
\hline
\end{tabular}

$*, * *$, and ${ }^{* * *}$ indicate statistical significance at $10 \%, 5 \%$, and $1 \%$ respectively. Standard errors are in parentheses. 
Table 6: Robustness Check 2: Effect of peer fund stability across fund complexes over a shorter time

This table presents the effect of peer funds' stability due to their enrollment in the Temporary Guarantee Program over a shorter period. The new analysis period is September 28-November 7, 2008, when the last fund announced its enrollment in the guarantee program.

Each column represents a different proxy of risk $\left(W_{k}\right)$ - (1): the equal weighting; (2): outflow right after Lehman's bankruptcy (September 15-19, 2008); (3): number of portfolios that had non-secured securities issued by Lehman Brothers; (4): log asset size of portfolios that had non-secured securities issued by Lehman Brothers; (5): number of portfolios that had non-agency repo transactions; (6): log asset size of portfolios that had non-agency repo transactions; (7): correlation between funds' gross yield for the past 12 months.

\begin{tabular}{llllllll}
\hline & $\begin{array}{c}\text { Proxy } \\
(1)\end{array}$ & \multicolumn{1}{c}{$\begin{array}{c}\text { Proxy } \\
(2)\end{array}$} & $\begin{array}{c}\text { Proxy } \\
(3)\end{array}$ & $\begin{array}{c}\text { Proxy } \\
(4)\end{array}$ & $\begin{array}{c}\text { Proxy } \\
(5)\end{array}$ & $\begin{array}{c}\text { Proxy } \\
(6)\end{array}$ & $\begin{array}{c}\text { Proxy } \\
(7)\end{array}$ \\
\hline Enroll $\times$ Peer Stability $(-2)$ & $-0.038^{* *}$ & $-0.004^{* *}$ & $-0.036^{* *}$ & $-0.029^{* *}$ & $-0.040^{* * *}$ & $-0.030^{* *}$ & $-0.033^{* *}$ \\
& $(0.02)$ & $(0.00)$ & $(0.01)$ & $(0.01)$ & $(0.01)$ & $(0.01)$ & $(0.01)$ \\
Enroll $\times$ Peer Stability $(-1)$ & -0.010 & $-0.003^{* *}$ & -0.010 & -0.014 & -0.006 & -0.008 & -0.013 \\
& $(0.02)$ & $(0.00)$ & $(0.01)$ & $(0.01)$ & $(0.01)$ & $(0.01)$ & $(0.01)$ \\
Enroll $\times$ Peer Stability $(0)$ & -0.015 & $-0.003^{* *}$ & -0.020 & -0.010 & -0.022 & -0.018 & -0.010 \\
& $(0.01)$ & $(0.00)$ & $(0.01)$ & $(0.01)$ & $(0.01)$ & $(0.01)$ & $(0.01)$ \\
Enroll & $0.661^{* * *}$ & $0.704^{* * *}$ & $0.620^{* * *}$ & $0.583^{* * *}$ & $0.669^{* * *}$ & $0.639^{* * *}$ & $0.554^{* * *}$ \\
& $(0.23)$ & $(0.17)$ & $(0.18)$ & $(0.17)$ & $(0.18)$ & $(0.18)$ & $(0.17)$ \\
Lagged Flow & $-0.511^{* * *}$ & $-0.510^{* * *}$ & $-0.511^{* * *}$ & $-0.511^{* * *}$ & $-0.511^{* * *}$ & $-0.511^{* * *}$ & $-0.511^{* * *}$ \\
& $(0.01)$ & $(0.01)$ & $(0.01)$ & $(0.01)$ & $(0.01)$ & $(0.01)$ & $(0.01)$ \\
Lagged Peer Fund Flow & -0.003 & -0.004 & -0.002 & -0.003 & -0.003 & -0.003 & -0.003 \\
Time FE & $(0.01)$ & $(0.01)$ & $(0.01)$ & $(0.01)$ & $(0.01)$ & $(0.01)$ & $(0.01)$ \\
Joint Test $\left(\left\{\beta_{1 \tau}\right\}_{\tau=0}^{\tau=2}\right)$ & Yes & Yes & Yes & Yes & Yes & Yes & Yes \\
N & 0.050 & 0.036 & 0.044 & 0.062 & 0.022 & 0.057 & 0.065 \\
\hline
\end{tabular}

$*, * *$, and $* * *$ indicate statistical significance at $10 \%, 5 \%$, and $1 \%$ respectively. Standard errors are in parentheses. 
Table 7: Robustness Check 3: Effect of peer fund stability across fund complexes over a shorter time

This table presents the effect of peer funds' stability due to their enrollment in the Temporary Guarantee Program over a shorter period. The new analysis period is September 28-October 8, 2008, during which funds had to actually file their application for the guarantee program.

Each column represents a different proxy of risk $\left(W_{k}\right)$ - (1): the equal weighting; (2): outflow right after Lehman's bankruptcy (September 15-19, 2008); (3): number of portfolios that had non-secured securities issued by Lehman Brothers; (4): log asset size of portfolios that had non-secured securities issued by Lehman Brothers; (5): number of portfolios that had non-agency repo transactions; (6): log asset size of portfolios that had non-agency repo transactions; (7): correlation between funds' gross yield for the past 12 months.

\begin{tabular}{llllllll}
\hline & \multicolumn{1}{c}{$\begin{array}{c}\text { Proxy } \\
(1)\end{array}$} & \multicolumn{1}{c}{$\begin{array}{c}\text { Proxy } \\
(2)\end{array}$} & $\begin{array}{c}\text { Proxy } \\
(3)\end{array}$ & $\begin{array}{c}\text { Proxy } \\
(4)\end{array}$ & $\begin{array}{c}\text { Proxy } \\
(5)\end{array}$ & $\begin{array}{c}\text { Proxy } \\
(6)\end{array}$ & $\begin{array}{c}\text { Proxy } \\
(7)\end{array}$ \\
\hline Enroll $\times$ Peer Stability $(-2)$ & -0.021 & -0.016 & -0.001 & -0.021 & -0.115 & -0.028 & -0.091 \\
& $(0.13)$ & $(0.02)$ & $(0.11)$ & $(0.11)$ & $(0.08)$ & $(0.08)$ & $(0.12)$ \\
Enroll $\times$ Peer Stability $(-1)$ & 0.045 & 0.008 & -0.005 & -0.016 & -0.068 & -0.050 & -0.002 \\
& $(0.15)$ & $(0.02)$ & $(0.14)$ & $(0.14)$ & $(0.10)$ & $(0.08)$ & $(0.15)$ \\
Enroll $\times$ Peer Stability $(0)$ & $-0.178^{* *}$ & $-0.017^{* *}$ & $-0.162^{* *}$ & $-0.133^{* *}$ & $-0.065^{* *}$ & $-0.114^{* * *}$ & -0.108 \\
& $(0.09)$ & $(0.01)$ & $(0.06)$ & $(0.06)$ & $(0.03)$ & $(0.04)$ & $(0.07)$ \\
Enroll & $2.171^{* *}$ & $1.888^{*}$ & $2.180^{* *}$ & $2.063^{* *}$ & $2.019^{* *}$ & $2.409^{* * *}$ & $1.726^{* *}$ \\
& $(0.93)$ & $(1.03)$ & $(0.92)$ & $(0.86)$ & $(0.86)$ & $(0.86)$ & $(0.73)$ \\
Lagged Flow & $-0.475^{* * *}$ & $-0.472^{* * *}$ & $-0.476^{* * *}$ & $-0.476^{* * *}$ & $-0.471^{* * *}$ & $-0.476^{* * *}$ & $-0.483^{* * *}$ \\
& $(0.03)$ & $(0.03)$ & $(0.03)$ & $(0.03)$ & $(0.03)$ & $(0.03)$ & $(0.03)$ \\
Lagged Peer Fund Flow & 0.009 & -0.002 & 0.007 & 0.007 & 0.008 & 0.002 & 0.014 \\
& $(0.01)$ & $(0.01)$ & $(0.01)$ & $(0.01)$ & $(0.01)$ & $(0.01)$ & $(0.01)$ \\
Time FE & Yes & Yes & Yes & Yes & Yes & Yes & Yes \\
Joint Test $\left(\left\{\beta_{1 \tau}\right\}_{\tau=0}^{\tau=2}\right)$ & 0.006 & 0.028 & 0.000 & 0.000 & 0.046 & 0.000 & 0.003 \\
\hline $\mathrm{N}$ & 1007 & 1007 & 1007 & 1007 & 1007 & 1007 & 1007 \\
\hline
\end{tabular}

$*, * *$, and $* * *$ indicate statistical significance at $10 \%, 5 \%$, and $1 \%$ respectively. Standard errors are in parentheses. 
Table 8: Robustness Check 4: Effect of peer fund stability across fund complexes without time fixed effects

This table presents the effect of peer funds' stability due to their enrollment in the Temporary Guarantee Program. We conduct the analysis without time fixed effects during September 28-December 19, 2008.

Each column represents a different proxy of risk $\left(W_{k}\right)$ - (1): the equal weighting; (2): outflow right after Lehman's bankruptcy (September 15-19, 2008); (3): number of portfolios that had non-secured securities issued by Lehman Brothers; (4): log asset size of portfolios that had non-secured securities issued by Lehman Brothers; (5): number of portfolios that had non-agency repo transactions; (6): log asset size of portfolios that had non-agency repo transactions; (7): correlation between funds' gross yield for the past 12 months.

\begin{tabular}{llllllll}
\hline & $\begin{array}{c}\text { Proxy } \\
(1)\end{array}$ & \multicolumn{1}{c}{$\begin{array}{c}\text { Proxy } \\
(2)\end{array}$} & $\begin{array}{c}\text { Proxy } \\
(3)\end{array}$ & $\begin{array}{c}\text { Proxy } \\
(4)\end{array}$ & $\begin{array}{l}\text { Proxy } \\
(5)\end{array}$ & $\begin{array}{c}\text { Proxy } \\
(6)\end{array}$ & $\begin{array}{c}\text { Proxy } \\
(7)\end{array}$ \\
\hline Enroll $\times$ Peer Stability $(-2)$ & $-0.045^{* * *}$ & $-0.007^{* * *}$ & $-0.031^{* * *}$ & $-0.027^{* * *}$ & $-0.039^{* * *}$ & $-0.027^{* * *}$ & $-0.042^{* * *}$ \\
& $(0.01)$ & $(0.00)$ & $(0.01)$ & $(0.01)$ & $(0.01)$ & $(0.01)$ & $(0.01)$ \\
Enroll $\times$ Peer Stability $(-1)$ & $-0.049^{* * *}$ & $-0.005^{* * *}$ & $-0.041^{* * *}$ & $-0.035^{* * *}$ & $-0.044^{* * *}$ & $-0.036^{* * *}$ & $-0.046^{* * *}$ \\
& $(0.01)$ & $(0.00)$ & $(0.01)$ & $(0.01)$ & $(0.01)$ & $(0.01)$ & $(0.01)$ \\
Enroll $\times$ Peer Stability $(0)$ & -0.005 & $-0.002^{* * *}$ & $-0.017^{* *}$ & $-0.011^{*}$ & $-0.014^{*}$ & $-0.017^{* *}$ & -0.009 \\
& $(0.01)$ & $(0.00)$ & $(0.01)$ & $(0.01)$ & $(0.01)$ & $(0.01)$ & $(0.01)$ \\
Enroll & $0.654^{* * *}$ & $0.653^{* * *}$ & $0.669^{* * *}$ & $0.567^{* * *}$ & $0.717^{* * *}$ & $0.681^{* * *}$ & $0.665^{* * *}$ \\
& $(0.11)$ & $(0.09)$ & $(0.11)$ & $(0.10)$ & $(0.11)$ & $(0.11)$ & $(0.11)$ \\
Lagged Flow & $-0.508^{* * *}$ & $-0.509^{* * *}$ & $-0.507^{* * *}$ & $-0.508^{* * *}$ & $-0.508^{* * *}$ & $-0.508^{* * *}$ & $-0.508^{* * *}$ \\
& $(0.01)$ & $(0.01)$ & $(0.01)$ & $(0.01)$ & $(0.01)$ & $(0.01)$ & $(0.01)$ \\
Lagged Peer Fund Flow & 0.004 & 0.004 & 0.004 & 0.004 & 0.004 & 0.004 & 0.004 \\
& $(0.00)$ & $(0.00)$ & $(0.00)$ & $(0.00)$ & $(0.00)$ & $(0.00)$ & $(0.00)$ \\
Time FE & No & No & No & No & No & No & No \\
Joint Test $\left(\left\{\beta_{1 \tau}\right\}_{\tau=0}^{\tau=2}\right)$ & 0.000 & 0.000 & 0.000 & 0.000 & 0.000 & 0.000 & 0.000 \\
\hline $\mathrm{N}$ & 9111 & 9111 & 9111 & 9111 & 9111 & 9111 & 9111 \\
\hline
\end{tabular}

$*, * *$, and $* * *$ indicate statistical significance at $10 \%, 5 \%$, and $1 \%$ respectively. Standard errors are in parentheses. 
Table 9: Robustness Check 5: Effect of peer fund stability across fund complexes with 3 days lag

This table presents the effect of peer funds' stability due to their enrollment in the Temporary Guarantee Program. We conduct the analysis again with a three-day lag of peer stability during September 28-December 19, 2008.

Each column represents a different proxy of risk $\left(W_{k}\right)$ - (1): the equal weighting; (2): outflow right after Lehman's bankruptcy (September 15-19, 2008); (3): number of portfolios that had non-secured securities issued by Lehman Brothers; (4): log asset size of portfolios that had non-secured securities issued by Lehman Brothers; (5): number of portfolios that had non-agency repo transactions; (6): log asset size of portfolios that had non-agency repo transactions; (7): correlation between funds' gross yield for the past 12 months.

\begin{tabular}{llllllll}
\hline & $\begin{array}{c}\text { Proxy } \\
(1)\end{array}$ & \multicolumn{1}{c}{$\begin{array}{c}\text { Proxy } \\
(2)\end{array}$} & \multicolumn{1}{c}{$\begin{array}{c}\text { Proxy } \\
(3)\end{array}$} & $\begin{array}{c}\text { Proxy } \\
(4)\end{array}$ & $\begin{array}{c}\text { Proxy } \\
(5)\end{array}$ & $\begin{array}{c}\text { Proxy } \\
(6)\end{array}$ & $\begin{array}{c}\text { Proxy } \\
(7)\end{array}$ \\
\hline Enroll $\times$ Peer Stability $_{(-3)}$ & 0.008 & -0.001 & $0.028^{*}$ & 0.019 & 0.021 & 0.011 & 0.002 \\
& $(0.02)$ & $(0.00)$ & $(0.02)$ & $(0.01)$ & $(0.02)$ & $(0.01)$ & $(0.01)$ \\
Enroll $\times$ Peer Stability $(-2)$ & $-0.041^{* *}$ & $-0.005^{* *}$ & $-0.042^{* *}$ & $-0.031^{* *}$ & $-0.045^{* * *}$ & $-0.034^{* *}$ & $-0.036^{* *}$ \\
& $(0.02)$ & $(0.00)$ & $(0.02)$ & $(0.01)$ & $(0.02)$ & $(0.01)$ & $(0.02)$ \\
Enroll $\times$ Peer Stability $(-1)$ & -0.012 & $-0.003^{*}$ & -0.006 & -0.013 & 0.000 & -0.005 & -0.015 \\
& $(0.02)$ & $(0.00)$ & $(0.02)$ & $(0.01)$ & $(0.01)$ & $(0.01)$ & $(0.02)$ \\
Enroll $\times$ Peer Stability $(0)$ & -0.015 & $-0.004^{* *}$ & -0.027 & -0.013 & $-0.033^{*}$ & -0.021 & -0.009 \\
& $(0.02)$ & $(0.00)$ & $(0.02)$ & $(0.01)$ & $(0.02)$ & $(0.01)$ & $(0.01)$ \\
Enroll & $0.717^{* *}$ & $0.777^{* * *}$ & $0.636^{* * *}$ & $0.620^{* * *}$ & $0.667^{* * *}$ & $0.624^{* * *}$ & $0.546^{* * *}$ \\
& $(0.28)$ & $(0.25)$ & $(0.20)$ & $(0.19)$ & $(0.21)$ & $(0.21)$ & $(0.19)$ \\
Lagged Flow & $-0.512^{* * *}$ & $-0.512^{* * *}$ & $-0.512^{* * *}$ & $-0.512^{* * *}$ & $-0.512^{* * *}$ & $-0.512^{* * *}$ & $-0.512^{* * *}$ \\
& $(0.01)$ & $(0.01)$ & $(0.01)$ & $(0.01)$ & $(0.01)$ & $(0.01)$ & $(0.01)$ \\
Lagged Peer Fund Flow & $0.006^{*}$ & $0.006^{*}$ & $0.006^{*}$ & $0.006^{*}$ & $0.006^{*}$ & $0.006^{*}$ & $0.006^{*}$ \\
\multirow{2}{*}{ Time FE } & $(0.00)$ & $(0.00)$ & $(0.00)$ & $(0.00)$ & $(0.00)$ & $(0.00)$ & $(0.00)$ \\
Joint Test $\left(\left\{\beta_{1 \tau}\right\}_{\tau=0}^{\tau=2}\right)$ & Yes & Yes & Yes & Yes & Yes & Yes & Yes \\
N & 0.138 & 0.106 & 0.044 & 0.083 & 0.034 & 0.086 & 0.152 \\
\hline
\end{tabular}

$*, * *$, and $* * *$ indicate statistical significance at $10 \%, 5 \%$, and $1 \%$ respectively. Standard errors are in parentheses. 
Table 10: Robustness Check 6: Effect of peer fund stability across fund complexes with credit default swap data

This table presents the effect of peer funds' stability due to their enrollment in the Temporary Guarantee Program. We conduct the analysis again with the credit default swap (CDS) rate of fund complexes during September 28-December 19, 2008. CDS rate data was available for 17 fund complexes from Thomson-Reuters (2012).

Each column represents a different proxy of risk $\left(W_{k}\right)$ - (1): the equal weighting; (2): outflow right after Lehman's bankruptcy (September 15-19, 2008); (3): number of portfolios that had non-secured securities issued by Lehman Brothers; (4): log asset size of portfolios that had non-secured securities issued by Lehman Brothers; (5): number of portfolios that had non-agency repo transactions; (6): log asset size of portfolios that had non-agency repo transactions; (7): correlation between funds' gross yield for the past 12 months.

\begin{tabular}{llllllll}
\hline & \multicolumn{1}{c}{$\begin{array}{c}\text { Proxy } \\
(1)\end{array}$} & $\begin{array}{c}\text { Proxy } \\
(2)\end{array}$ & \multicolumn{1}{c}{$\begin{array}{c}\text { Proxy } \\
(3)\end{array}$} & $\begin{array}{c}\text { Proxy } \\
(4)\end{array}$ & $\begin{array}{c}\text { Proxy } \\
(5)\end{array}$ & $\begin{array}{c}\text { Proxy } \\
(6)\end{array}$ & $\begin{array}{c}\text { Proxy } \\
(7)\end{array}$ \\
\hline Enroll $\times$ Peer Stability $(-2)$ & $-0.097^{* *}$ & -0.013 & $-0.106^{* *}$ & $-0.069^{* *}$ & $-0.092^{* *}$ & $-0.080^{* *}$ & $-0.097^{* *}$ \\
& $(0.05)$ & $(0.01)$ & $(0.05)$ & $(0.03)$ & $(0.04)$ & $(0.04)$ & $(0.04)$ \\
Enroll $\times$ Peer Stability $(-1)$ & -0.056 & -0.007 & -0.047 & $-0.059^{*}$ & -0.038 & -0.052 & -0.069 \\
& $(0.05)$ & $(0.01)$ & $(0.04)$ & $(0.04)$ & $(0.04)$ & $(0.04)$ & $(0.04)$ \\
Enroll $\times$ Peer Stability $(0)$ & -0.005 & -0.008 & -0.031 & -0.003 & -0.043 & -0.024 & -0.009 \\
& $(0.04)$ & $(0.01)$ & $(0.05)$ & $(0.03)$ & $(0.05)$ & $(0.04)$ & $(0.04)$ \\
Enroll & $1.722^{* *}$ & $1.527^{* *}$ & $1.499^{* *}$ & $1.983^{* * *}$ & $1.593^{* *}$ & $1.652^{* *}$ & $1.406^{* *}$ \\
& $(0.80)$ & $(0.66)$ & $(0.72)$ & $(0.62)$ & $(0.80)$ & $(0.78)$ & $(0.58)$ \\
Lagged Flow & $-0.505^{* * *}$ & $-0.506^{* * *}$ & $-0.505^{* * *}$ & $-0.506^{* * *}$ & $-0.506^{* * *}$ & $-0.506^{* * *}$ & $-0.506^{* * *}$ \\
& $(0.02)$ & $(0.02)$ & $(0.02)$ & $(0.02)$ & $(0.02)$ & $(0.02)$ & $(0.02)$ \\
Lagged Peer Fund Flow & 0.010 & 0.009 & 0.010 & 0.009 & 0.009 & 0.009 & 0.010 \\
& $(0.01)$ & $(0.01)$ & $(0.01)$ & $(0.01)$ & $(0.01)$ & $(0.01)$ & $(0.01)$ \\
CDS & -0.007 & -0.006 & -0.015 & -0.008 & -0.010 & -0.012 & -0.005 \\
\multirow{2}{*}{ Time FE } & $(0.03)$ & $(0.04)$ & $(0.03)$ & $(0.03)$ & $(0.04)$ & $(0.04)$ & $(0.03)$ \\
Joint Test $\left(\left\{\beta_{1 \tau}\right\}_{\tau=0}^{\tau=2}\right)$ & Yes & Yes & Yes & Yes & Yes & Yes & Yes \\
\hline $\mathrm{N}$ & 0.172 & 0.209 & 0.113 & 0.114 & 0.180 & 0.181 & 0.077 \\
\hline
\end{tabular}

$*^{* *}$, and $* * *$ indicate statistical significance at $10 \%, 5 \%$, and $1 \%$ respectively. Standard errors are in parentheses. 


\section{C.2 Additional analysis: contagious runs within a fund complex}

\section{C.2.1 Hypothesis development: contagious runs within a fund complex}

An additional hypothesis we test is whether investors in money market funds withdrew their investments because they were concerned about their arms-length peer funds' withdrawals in the same fund complex. This hypothesis is related to the relationship between money market funds and the sponsoring company. If one fund in a fund complex experiences a run by investors and must sell its assets at a distressed price, the fund's NAV might fall below $\$ 0.995$. To prevent this incidence, the fund-sponsoring company might provide additional liquidity to support the $\$ 1 \mathrm{NAV}$. Other funds within the same sponsoring company are sharing a common liquidity pool that can be used to support each fund. If an investor believes peer funds in the same fund complex will be run by their investors, potentially depleting the sponsoring company's liquidity pool, the investor is more likely to withdraw from the fund. This mechanism generates a self-fulfilling crisis within the fund complex, even though investment fundamentals in each fund may be sound enough to produce higher yields in the long run. This mechanism is developed more formally in Section $\mathrm{A}$, using a global game framework. Therefore, our another goal is to test for the existence of a panic-driven contagious run within a fund complex.

Hypothesis: Investors' redemption requests were positively influenced by peers' redemption requests in the same fund complex.

Identifying this peer effect can be challenging, because abrupt redemption requests may be due to unobserved common shocks (for example, sponsor risk). For this reason, the Ordinary Least Squares (OLS) estimates may embed a spurious correlation even though there may be no causal link among peers' redemption requests (Manski (1993)). In our study, we use panel data structure to control for unobserved common shocks and to test for the impact of such peer or strategic complementarity effects immediately following the Lehman Brothers' collapse.

\section{C.2.2 Empirical analysis}

We also investigate whether there was a contagion risk of runs within fund complexes, immediately following the Lehman Brothers' collapse. In pursuit of our empirical goal, we estimate the following model:

$$
\operatorname{Flow}_{f, c, t}=\alpha+\beta_{0} t+\beta_{1} \overline{F l o w}_{c(-f), t-1}+\beta_{2} \operatorname{Flow}_{f, c, t-1}+\beta_{3} X_{t}+\beta_{4} \overline{F l o w}_{(-c), t-1}+\tau_{c, t}+u_{f, c, t}
$$


The dependent variable Flow $_{f, c, t}$ is the fund flow for fund $f$ in fund complex $c$ between time $t-1$ and $t$. Following the standard practice in mutual fund literature, we measure fund flow by $F l o w_{f, c, t} \equiv$

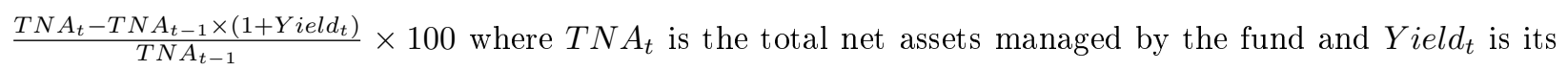
(daily) return. Covariates include the following:

- $\overline{F l o w}_{c(-f), t-1}$ is average lagged flows of peer funds defined as $\frac{\sum_{k \neq f} T N A_{k, c, t-1}-\sum_{k \neq f} T N A_{k, c, t-2} \times\left(1+Y i e l d_{k, c, t-1}\right)}{\sum_{k \neq f} T N A_{k, c, t-2}} \times$ 100 where $T N A_{k, c, t}$ is the total net asset of fund $k$ in fund complex $c$ at time $t$

- Flow $_{f, c, t-1}$ is lagged flow for the own fund $f$;

- $\overline{\operatorname{Flow}}_{(-c), t-1}$ is average lagged flows of peer fund complexes defined as $\frac{\sum_{k \neq c} T N A_{k, t-1}-\sum_{k \neq c} T N A_{k, t-2} \times\left(1+Y i e l d_{k, t-1}\right)}{\sum_{k \neq c} T N A_{k, t-2}} \times$ 100 where $T N A_{k, t}$ is the total asset size of fund complex $k$ at time $t$;

- $X_{t}$ is a marketwide variable at time $t$ (for example, VIX index);

- $\tau_{c, t}$ : unobservable fund complex-level shock; and

- $\epsilon_{f, c, t}$ : idiosyncratic shock.

Our assumption is that peer funds' flows are observed with a lag. This assumption is realistic, because the shortest data frequency is daily: Investors could not contemporaneously observe their peer investors action but they could observe daily fund flows with lags. Another advantage of assuming a delayed impact of peer funds' flows is that a simultaneity problem between one's own and peer funds flows does not arise in this case (Manski (1993)).

The coefficient of interest is $\beta_{1}$, which reflects the sensitivity of a fund $f$ 's flow to peer funds' flows with a one-day lag. With a causal interpretation, positive $\beta_{1}$ implies that investors in fund $f$ were more likely to withdraw in response to their peer investors' withdrawals from the same fund complex. That is, because of their peers' actions, investors were herding in the same direction.

In a cross-sectional setting, it is challenging to identify the peer effect because a common shock to all investors in the same fund complex $\left(\tau_{c, t}\right)$ can generate a spurious correlation in investor behaviors (Manski $(1993)$ ). For example, investors could withdraw from a fund when they perceived that the fund's sponsoring company was unable to support the fund (fund complex level common shock $\tau_{c, t}$ ). In such cases, all investors might withdraw due to a common shock rather than the fear of peer withdrawals, so the OLS estimate of the coefficient would reflect a spuriously positive correlation even if investors did not react to other investors' behaviors. Thus, this correlation cannot be interpreted as a causal peer effect.

To overcome these difficulties, we use a panel data structure with daily fund flows. Assuming that fund complex shocks $\left(\tau_{c, t}\right)$ are additively decomposable into time-invariant and time-specific parts, we can 
identify separately the peer effect from the correlation effect by introducing fund complex fixed effects and time fixed effects. Allowing for potentially strong serial correlation in $\epsilon_{f, c, t}$ which is commonly observable in high frequency data during financial market turmoil ${ }^{47}$ we first-difference the empirical model to have the following:

$$
\Delta \text { Flow }_{f, c, t}=\beta_{0}+\beta_{1} \Delta \overline{F l o w}_{c(-f), t-1}+\beta_{2} \Delta \text { Flow }_{f, c, t-1}+\beta_{3} \Delta X_{t}+\beta_{4} \Delta \overline{F l o w}_{(-c), t-1}+\Delta u_{f, c, t}
$$

We run this regression for the analysis period of September 15, 2008 (when Lehman collapsed) through September 28, 2008 (when the TGP application window opened).

Estimation results are presented in Table 11 , where the peer effect $\left(\beta_{1}\right)$ in the first row is the coefficient of interest. Columns $1-3$ present results of OLS regression with one's own fund's one-day lagged flows and columns 4-6 present results of OLS regression with two-day lagged flows. In columns (3) and (6), we control time fixed effects and find a stong positive effect of peer funds' lagged flow on the own fund's flow. The positive coefficient estimate of the variable "peer funds' flow" indicates that investors were herding in the same direction (either withdrawing or investing) along with their peers. These results support Hypothesis 2 concerning contagious runs within fund complexes. Moreover, the coefficient's economic significance is substantial. With a one-day lag, the peer effect $\left(\beta_{1}\right)$ is 6.5 percentage points. Considering the median asset size of a fund ( $\$ 5$ billion) on September 15, 2008 and the average magnitude of the peer funds' daily withdrawal ( $0.9 \%$ a day), a fund experienced, on a conservative measure, $\$ 2.9$ million in outflows per day, when a peer fund within the same complex was withdrawn by investors.

\footnotetext{
${ }^{47}$ More specifically, we assume $u_{f, c, t}=u_{f, c, t-1}+\epsilon_{f, c, t}$ where $\left\{\epsilon_{f, c, t}\right\}_{t}$ are serially uncorrelated and independent with $u_{f, c, t-1}$. This assumption implies that yesterday's idiosyncratic shock to investors is not attenuated much and affects today's investors behavior with similar magnitude combined with a white noise. The 'non-attenuatedness' assumption is realistic in our setting because we are considering investors' behavior with a very short frequency (i.e., daily).
} 
Table 11: Effects of peer fund stability on one's own fund flows: Within fund complexes

This table presents the evidence of the strategic complementarity of investors within a fund complex. We specify a regression model:

$$
\text { Flow }_{f, c, t}=\alpha+\beta_{0} t+\beta_{1} \overline{F l o w}_{c(-f), t-1}+\beta_{2} \text { Flow }_{f, c, t-1}+\beta_{3} X_{t}+\beta_{4} \overline{F l o w}_{(-c), t-1}+\tau_{c, t}+u_{f, c, t}
$$

where $c$ is fund complex, $f$ is fund, and $t$ is time. The dependent variable is the flows of fund $f$ in a fund complex $c$ at period t. Flow $w_{c(-f), t-1}$ is peer funds' flows in the same fund complex except the fund $f . X_{t}$ is a marketwide variable at time $t$ such as the VIX index, $\overline{F l o w}_{(-c), t-1}$ is average flows of peer fund complex, $\tau_{c, t}$ is an unobservable fund complex level shock, and $\epsilon_{f, c, t}$ is an idiosyncratic shock to fund $f$ in complex $c$ at time $t$. The analysis period is September $15-28,2008$. To control for unobservable shocks at a fund complex levels, a first-differenced model is estimated. Additionally, to control for unobservable time-specific shock, the model is estimated with time fixed effects in some specifications. Columns $1-3$ present the results of OLS regression with own fund's one-day lagged flows and columns $4-6$ present the results of OLS regression with own funds' two-day lagged flows.

The coefficient of interest is the impact of peer funds' flows on own fund flows $\left(\beta_{1}\right)$. The positive coefficient estimate of the variable "peer funds flows" implies that investors were herding in the same direction (either withdrawing or investing) because of their peers' similar actions.

\begin{tabular}{|c|c|c|c|c|c|c|}
\hline & (1) & (2) & (3) & (4) & (5) & (6) \\
\hline Peer Funds' Flow $_{t-1}$ & $\begin{array}{l}0.047^{* *} \\
(0.02)\end{array}$ & $\begin{array}{l}0.045^{*} \\
(0.02)\end{array}$ & $\begin{array}{l}0.065^{* *} \\
(0.03)\end{array}$ & $\begin{array}{l}0.066^{* *} \\
(0.03)\end{array}$ & $\begin{array}{l}0.064^{* *} \\
(0.03)\end{array}$ & $\begin{array}{l}0.089^{* * * *} \\
(0.03)\end{array}$ \\
\hline Own Fund's Flow $t-1$ & $\begin{array}{l}-0.476^{* * *} \\
(0.04)\end{array}$ & $\begin{array}{l}-0.477^{* * *} \\
(0.04)\end{array}$ & $\begin{array}{l}-0.472^{* * *} \\
(0.04)\end{array}$ & $\begin{array}{l}-0.621^{* * *} \\
(0.06)\end{array}$ & $\begin{array}{l}-0.620^{* * *} \\
(0.07)\end{array}$ & $\begin{array}{l}-0.617^{* * *} \\
(0.06)\end{array}$ \\
\hline Own Fund's Flow ${ }_{t-2}$ & & & & $\begin{array}{l}-0.349^{* * *} \\
(0.05)\end{array}$ & $\begin{array}{l}-0.345^{* * *} \\
(0.05)\end{array}$ & $\begin{array}{l}-0.351^{* * *} \\
(0.05)\end{array}$ \\
\hline Peer Complexes' Flow ${ }_{t-1}$ & $\begin{array}{l}0.140^{* *} \\
(0.06)\end{array}$ & $\begin{array}{l}0.215^{* * *} \\
(0.07)\end{array}$ & $\begin{array}{l}5.514^{*} \\
(3.01)\end{array}$ & $\begin{array}{l}0.192^{* * * *} \\
(0.06)\end{array}$ & $\begin{array}{l}0.256^{* * *} \\
(0.06)\end{array}$ & $\begin{array}{l}6.703 \\
(4.20)\end{array}$ \\
\hline VIX Index $_{t}$ & & $\begin{array}{l}-0.190^{* * *} \\
(0.06)\end{array}$ & & & $\begin{array}{l}-0.163^{* * *} \\
(0.05)\end{array}$ & \\
\hline Constant & $\begin{array}{c}-0.016 \\
(0.04)\end{array}$ & $\begin{array}{l}0.061 \\
(0.05)\end{array}$ & $\begin{array}{l}9.286^{*} \\
(5.23)\end{array}$ & $\begin{array}{c}-0.018 \\
(0.05)\end{array}$ & $\begin{array}{l}0.048 \\
(0.05)\end{array}$ & $\begin{array}{l}11.237 \\
(7.30)\end{array}$ \\
\hline Time FE & No & No & Yes & No & No & Yes \\
\hline $\mathrm{N}$ & 1530 & 1530 & 1530 & 1530 & 1530 & 1530 \\
\hline
\end{tabular}

$*, * *$, and $* * *$ indicate statistical significance at $10 \%, 5 \%$, and $1 \%$ respectively. Standard errors are in parentheses. 